\title{
Characterization of Recharge Mechanisms and Sources of Groundwater Salinization in Ras Jbel Coastal Aquifer (Northeast Tunisia) Using Hydrogeochemical Tools, Environmental Isotopes, GIS, and Statistics
}

\author{
Jamila Hammami Abidi, ${ }^{1}$ Boutheina Farhat, ${ }^{1}$ \\ Abdallah Ben Mammou, ${ }^{1}$ and Naceur Oueslati ${ }^{2}$ \\ ${ }^{1}$ Faculty of Sciences of Tunis, Laboratory of Mineral Resources and Environment, University of Tunis El Manar, 2092 Tunis, Tunisia \\ ${ }^{2}$ Regional Commission for Agricultural Development, av. Hassen Nouri, 7000 Bizerte, Tunisia
}

Correspondence should be addressed to Jamila Hammami Abidi; hammami.jamila@yahoo.fr

Received 25 November 2016; Accepted 5 February 2017; Published 8 May 2017

Academic Editor: Franco Frau

Copyright ( 2017 Jamila Hammami Abidi et al. This is an open access article distributed under the Creative Commons Attribution License, which permits unrestricted use, distribution, and reproduction in any medium, provided the original work is properly cited.

\begin{abstract}
Groundwater is among the most available water resources in Tunisia; it is a vital natural resource in arid and semiarid regions. Located in north-eastern Tunisia, the Metline-Ras Jbel-Raf Raf aquifer is a mio-plio-quaternary shallow coastal aquifer, where groundwater is the most important source of water supply. The major ion hydrochemistry and environmental isotope composition $\left(\delta^{18} \mathrm{O}, \delta^{2} \mathrm{H}\right)$ were investigated to identify the recharge sources and processes that affect the groundwater salinization. The combination of hydrogeochemical, isotopic, statistical, and GIS approaches demonstrates that the salinity and the groundwater composition are largely controlled by the water-rock interaction particularly the dissolution of evaporate minerals and the ion exchange process, the return flow of the irrigation water, agricultural fertilizers, and finally saltwater intrusion which started before 1980 and which is partially mitigated by the artificial recharge since 1993. As for the stable isotope signatures, results showed that groundwater samples lay on and around the local meteoric water line LMWL; hence, this arrangement signifies that the recharge of the Ras Jbel aquifer is ensured by recent recharge from Mediterranean air masses.
\end{abstract}

\section{Introduction}

The hydrogeology of coastal aquifers has been studied intensively during the past decades, stimulated by both scientific interest and societal relevance [1]. Coastal areas throughout the Mediterranean face salinization problems of groundwater which is the major source of water supply especially for drinking and agricultural sector. The imbalance between abstraction and natural recharge rates causes an overexploitation of groundwater resources resulting in declining groundwater table, water quality degradation, and crop damage.

A number of aquifers in coastal zones are being increasingly exploited and affected ([2-6]). For instance, groundwater contamination and decline of water levels have been reported in Tunisia [7-13] and in many countries around the world. It has been reported in India [14], Jordan [15], Australia [16], USA [17], China ([18, 19]), Netherland [1], and among many others.

In semiarid coastal regions of north-eastern Tunisia, such as Ras Jbel plain, the groundwater is usually the main resource used for irrigation and drinking purposes. Nevertheless, salinization is becoming a common problem affecting groundwater resources. Groundwater exploitation of the Ras Jbel aquifer began in 1949 and has increased each year since 1980. Under pressures of population, climate change, and pollution, the aquifer faces substantial challenges in the management of scarce freshwater resources. During the last four decades, the shallow aquifer groundwater has been overexploited through excessive, uncontrolled pumping mainly for domestic and agricultural purposes [20]. Salinization 

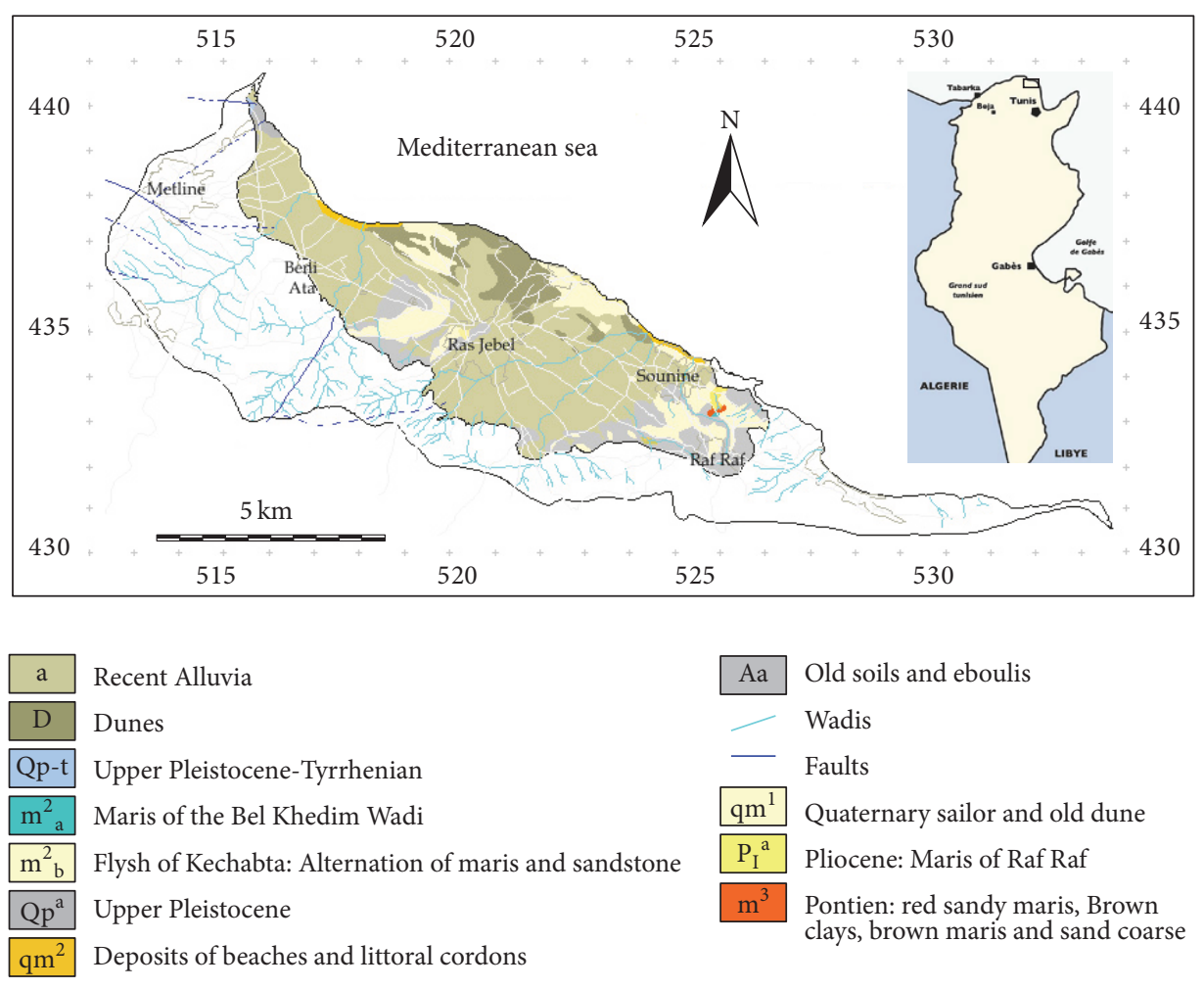

FIGURE 1: Geological and location map of the study area [28-30].

due to seawater intrusion and decreasing groundwater levels has recently been identified [21]. Unplanned and substantial withdrawals of groundwater from the shallow aquifer of Ras Jbel have resulted in severe water level decline of up to $7 \mathrm{~m}$ in some areas and high total dissolved solids (TDS) contents reaching $8000 \mathrm{mg} / \mathrm{l}$. Reports of increasing salinity of groundwater supplies in the area suggest a need to define the sources of salt water. It is also useful to study the recharge mechanisms as well as the mixing fresh water/saline water.

Stable isotope and geochemical techniques have been used in groundwater studies of coastal aquifers worldwide [22-25] for determining the origins of groundwater salinization in aquifers and processes that affect water chemistry, such as rock weathering, evaporation, atmospheric precipitation, and cation exchange. Consequently, studying stable isotope and geochemical techniques can significantly improve our understanding of groundwater hydrodynamical processes and chemical evolution [26]. In the present study, environmental isotopes $\left(\delta^{18} \mathrm{O}, \delta^{2} \mathrm{H}\right)$ in conjunction with hydrochemistry (major ions) were employed (1) to define the potential sources and different mechanisms of groundwater salinization in the study area (2) to discuss the chemical evolution of groundwater and (3) to explain groundwater recharge and discharge in the coastal plain of Metline- Ras Jbel- Raf Raf.

\section{Study Area}

The Metline-Ras Jbel-Raf Raf plain, which covers a total area of about $50 \mathrm{~km}^{2}$, represents one of the most important

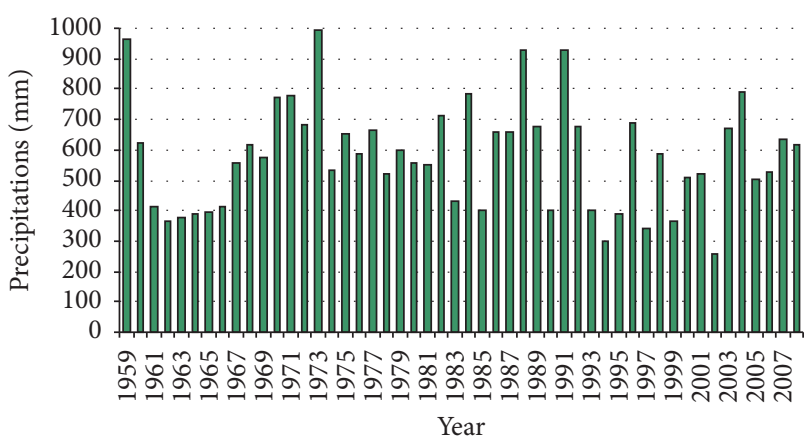

FIGURE 2: Yearly precipitation in Metline-Ras Jbel-Raf Raf plain [64, 65].

agricultural regions in north-eastern Tunisia (Figure 1). It is characterized by a semiarid, "Mediterranean" climate with mild, wet winters and warm, dry summers $[27,28]$. The average annual precipitation ranges from approximately 258 to $993 \mathrm{~mm}$ (Figure 2). Geologically, it is limited to the south by Jbel Djaouf, En Nadhour, and Ed Demina, to the southwest by Jbel Sidi Saleh, Hakima, and El Faouar, to northwest by Jbel Bab Banzart, Sidi Bou Choucha, and Touchela, to the north and northeast by the Mediterranean sea. The plain of MetlineRas Jbel-Raf Raf is a wide basin of collapse, formed by a subsidence followed by an alluvial and recent sedimentation. It is affected by folding and faults in NW-SE and SSW-NNE directions. Sedimentary series extend from Miocene to Quaternary. The lithological description of these sediments [2830] reveals that the Miocene is represented by the Kechabta 


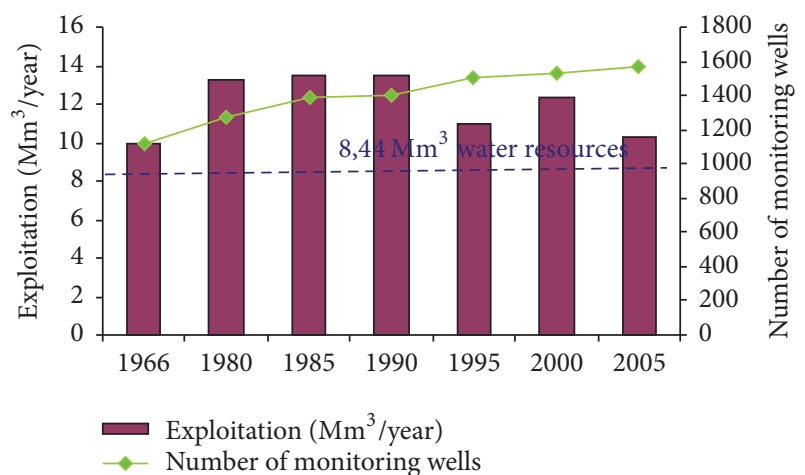

FIGURE 3: Evolution of the exploitation rate and the monitoring well number of the shallow aquifer of Ras Jbel during 1966 and 2005 [30, 31].

and Wadi Bel Khedim formations. The Kechabta formation has a thickness of about $1000 \mathrm{~m}$ and consists of alternation of marls and fine sandstone benches. The Wadi Bel Khedim formation is of $250 \mathrm{~m}$ thickness. At the east of Raf Raf, it is composed of large outcrops of gray marls with gypsum benches. The Quaternary series unconformably overlie the Miocene series and is divided into seven units (from bottom to the top $\mathrm{qm}^{1}, \mathrm{Aa}, \mathrm{qm}^{2}, \mathrm{Qp}^{\mathrm{a}}, \mathrm{Qp}$-t, D and a).

Hydrologically, the Quaternary series and the current formations, characterized by their extension and their good permeability, host the shallow aquifer of Ras Jbel. This aquifer is recharged by local infiltration on the plain, by water flowing from the surrounding hills, and from the different rivers crossing the plain: Wadi Beni Ata and Wadi Ali in Beni Ata region, Wadi El Kantra, El Blaat, and El Ma in Ras Jbel region, Wadi Sandid draining the zone of Raf Raf and Wadi El Kantra in the region of Dar El Khaddar. Pumping tests showed that transmissivity can reach $15.10^{-4} \mathrm{~m}^{2} / \mathrm{s}$. The most transmissive areas are the low alluvial plain of Bahirat Beni Ata, the low alluvial area of Wadi El Krib and El Aouinet, and the upstream area of Ain Cherchar, Ain Ezzaouia, Ain Kassa, and Ain El Hammam, as well as the sandstone dune of Ain El Mestir and Ain Mahloul.

The shallow aquifer of Ras Jbel is affected by natural and anthropogenic factors like evaporation, irrigation, pumping, and so forth. The aquifer is tapped by several private and state owned wells. In the period between 1985 and 1990, the exploitation rate was estimated at $13,5 \mathrm{Mm}^{3}$ / year, which exceeded the renewable resources evaluated at $8,44 \mathrm{Mm}^{3} /$ year [31]. The total number of dug wells has been estimated to be 1387 in 1985, 1396 in 1990, and 1563 in 2005. In 2005 , the exploitation rate was estimated at $10,27 \mathrm{Mm}^{3} /$ year (Figure 3). The massive exploitation of aquifer resources in response to the heavy pumping caused a drop in the water level (Figure 4) and the deterioration of water quality. In 1949 , the salinity of the groundwater varied between 648 and $1692 \mathrm{mg} / \mathrm{l}$ [32]. The investigations carried out by the DGRE between 1985 and 1993 through several monitoring wells revealed the existence of a very saline groundwater. The degradation of the water quality has been detected mainly in coastal areas where salt concentrations exceeded $15 \mathrm{~g} / \mathrm{l}$ in 1985 and $8 \mathrm{~g} / \mathrm{l}$ in 1993 and in the depression of Bahirat Beni Ata where the ante-quaternary substratum is below the sea level [21].

\section{Methods}

3.1. Water Sampling and Chemical Analysis. Ninety-four samples (including pumping wells and piezometers) were collected for geochemical analysis (major elements) and isotopes $\left(\delta^{2} \mathrm{H}, \delta^{18} \mathrm{O}\right)$ during the wet and the dry season of March and July 2007 (Figure 5). Sampling locations were recorded using a potable GPS device. Prior to sampling, all wells were pumped for several minutes to eliminate the influence from stagnant water. Samples were collected in cleaned polyethylene bottles, tightly capped and stored at $4^{\circ} \mathrm{C}$ until analysis. Electrical conductivity (EC), salinity, and $\mathrm{pH}$ were measured in the field using a portable conductivity, salinity, and $\mathrm{pH}$ meter.

Chemical analyses were done using a Varian 730-ES ICP Optical Emission Spectrometer for cations and using ion chromatography (DX-120, Dionex, USA) for anions. $\mathrm{HCO}_{3}{ }^{-}$ was measured by titration (Hach, USA). Samples for stable isotope analysis were collected according to the procedures described by Clark and Fritz [33]. Isotopic analyses were conducted in the isotopic laboratory of the department of Hydrology and Geo-environmental Sciences of the Faculty of Earth and Live Sciences of the Free University of Amsterdam. Isotopic ratios are expressed in per mil $(\delta)$ and oxygen and hydrogen isotope analyses were reported to $d$ notation relative to Vienna Standard Mean Oceanic Water (V-SMOW), where $d=[($ Rs $/$ RVSMOW $)-1] \times 1000$, Rs represents either the ${ }^{18} \mathrm{O} /{ }^{16} \mathrm{O}$ or the ${ }^{2} \mathrm{H} /{ }^{1} \mathrm{H}$ ratio of the sample, and RSMOW is ${ }^{18} \mathrm{O} /{ }^{16} \mathrm{O}$ or the ${ }^{2} \mathrm{H} /{ }^{1} \mathrm{H}$ ratio of the SMOW. Typical precisions are \pm 0.1 and $\pm 1 \%$ for oxygen- 18 and deuterium, respectively.

3.2. Statistical Analysis. The physicochemical parameters and chemical composition of the groundwater samples are presented in Table 1 . All the acquired data were integrated into hydrogeochemical database in order to study the groundwater quality and to identify the groundwater salinization processes that contributed to the acquisition of the actual chemical composition.

Piper plots [34], considered as the common method for a multiple analyses on the same graph, are used to represent the different water samples and to distinguish graphically between different water types defined by the Stuyfzand classification (1993). Sample points with similar hydrochemistry tend to cluster together in the diagram [35].

Principal component analysis method (PCA) and correlations are a popular method to assess groundwater quality. One of the principle advantages of multivariate techniques such as principal component analysis (PCA) is that they are able to rapidly reveal relationships between a large number of variables. In this study, PCA and correlations are used to identify the possible sources of major ions in groundwater, hydrogeological reactions that may occur in the study area, and dominant factors that control groundwater quality.

Gibbs diagrams which are a simple plot of the TDS versus the weight ratio of $\mathrm{Na}^{+} /\left(\mathrm{Na}^{+}+\mathrm{Ca}^{2+}\right)$ or $\mathrm{Cl}^{-} /\left(\mathrm{Cl}^{-}+\mathrm{HCO}_{3}{ }^{-}\right)$ 


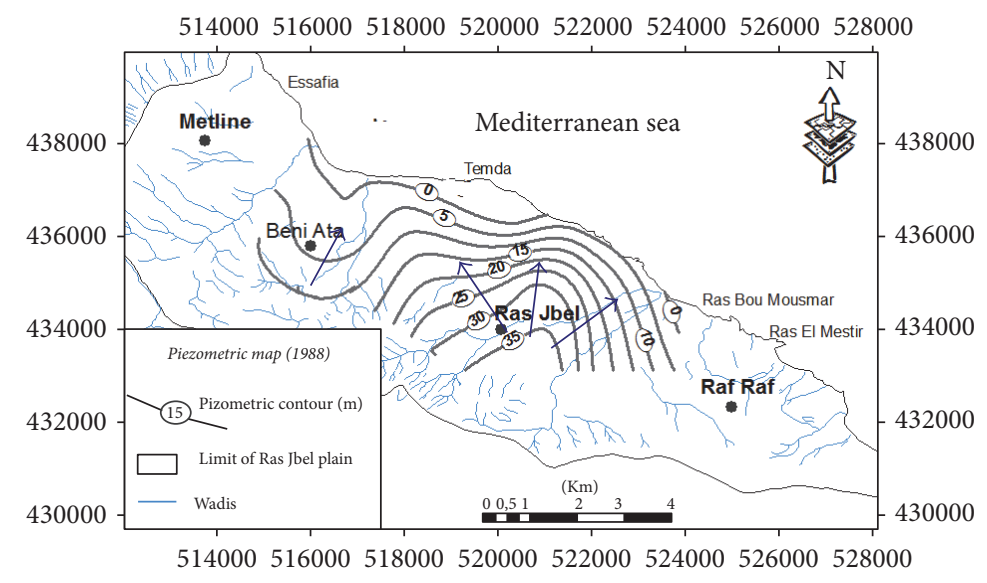

FIGURE 4: Piezometric contour maps of the study area [31].

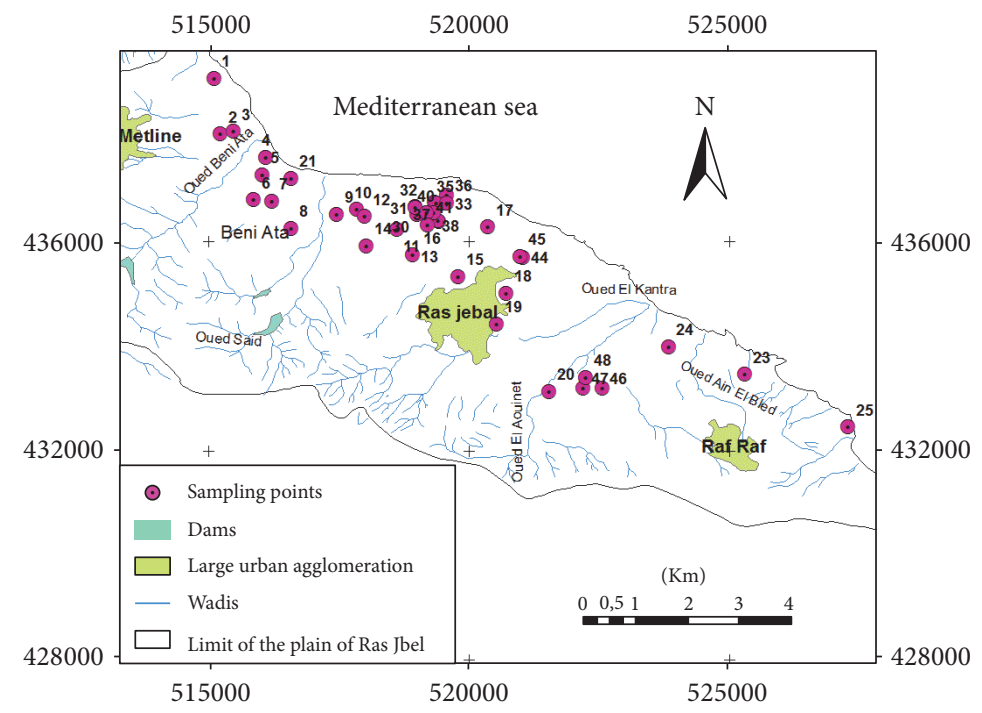

FIGURE 5: Location of sampled wells and piezometers in the study area.

are widely used to establish the relationships between the water composition and the lithological characteristics of the aquifer [36]. Three distinct fields, including precipitation dominance, evaporation dominance, and rock weathering dominance, constitute the segments in the Gibbs diagram.

Hydrogeochemical Modeling. The equilibrium state of the water with respect to a mineral phase can be determined by calculating saturation index (SI) using analytical data. In this study, saturation indices (SI) were calculated in terms of the following equation [37]:

$$
\mathrm{SI}=\log \left(\frac{\mathrm{IAP}}{k_{s}(T)}\right)
$$

where IAP is the relevant ion activity product, which can be calculated by multiplying the ion activity coefficient $\gamma i$ and the composition concentration $m_{i}$, and $k_{s}(T)$ is the equilibrium constant of the reaction considered at the sample temperature [35]. The geochemical modeling program PHREEQC has been used to evaluate the water chemistry.
SI $>0$ indicates oversaturation and minerals may be subject to precipitation, $\mathrm{SI}<0$ means undersaturation and minerals will dissolve, and $\mathrm{SI}=0$ suggests saturation and minerals are in equilibrium status with respect to the solution [38].

\section{Results and Discussion}

4.1. Hydrogeochemical Characterization. Groundwater quality depends on various chemical constituents and their concentrations, which are mostly derived from the geological stratum of the particular region [6]. The $\mathrm{pH}$ was one of the primary indicators of the water chemistry evolution. The aquifer groundwater was neutral to slightly alkaline water, with a mean $\mathrm{pH}$ value of 7,23 and 7,15 in the wet and dry season, respectively. Electrical conductivity (EC) of the water samples was medium to high, suggestive of very highly mineralized waters. EC values ranged between 1240 and $6300 \mu \mathrm{S} / \mathrm{cm}$ in the wet season and between 1131 and $5430 \mu \mathrm{S} /$ $\mathrm{cm}$ in the dry season. A problem to the water supply development in the area is the increasing electrical conductivity 


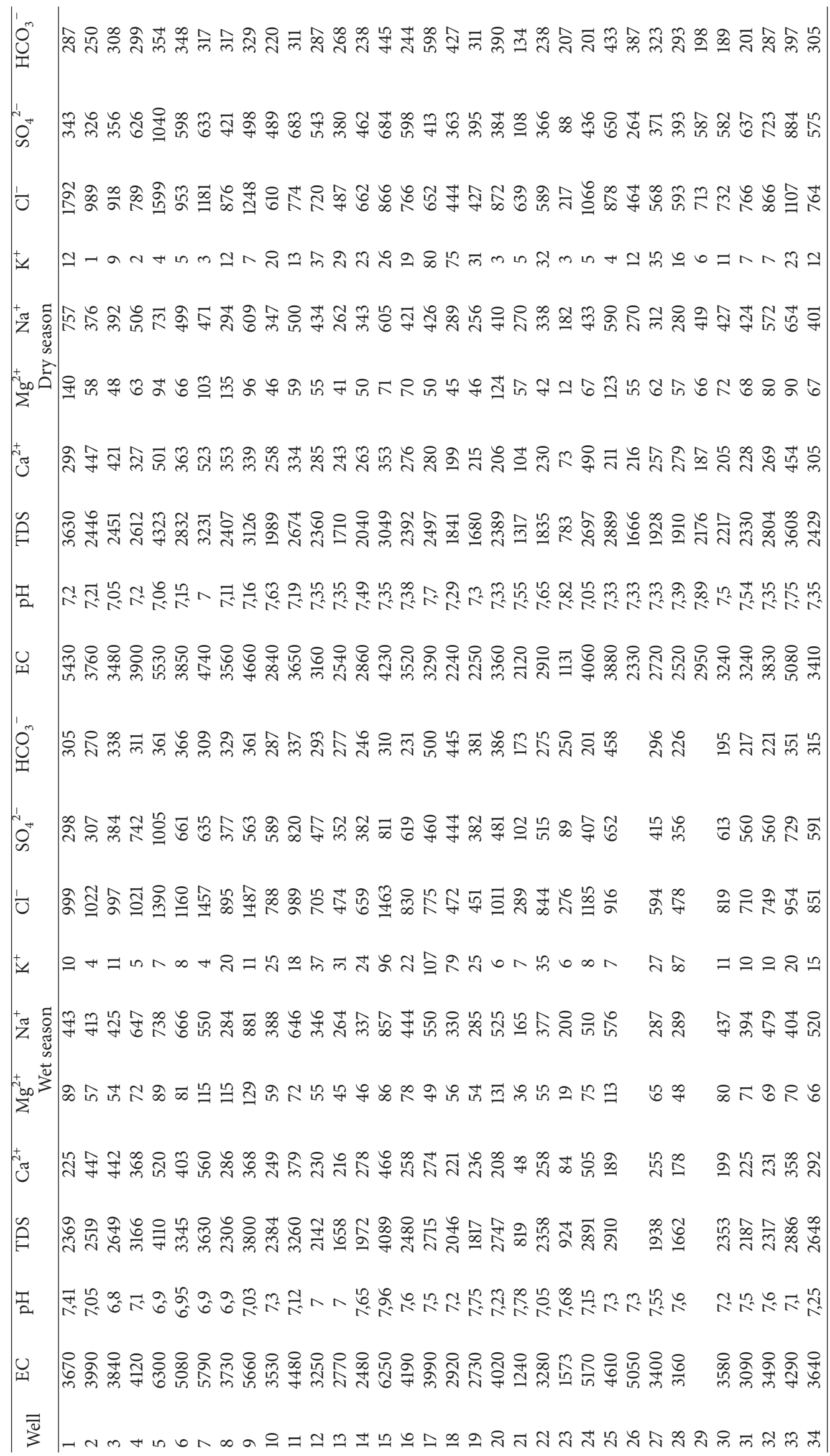




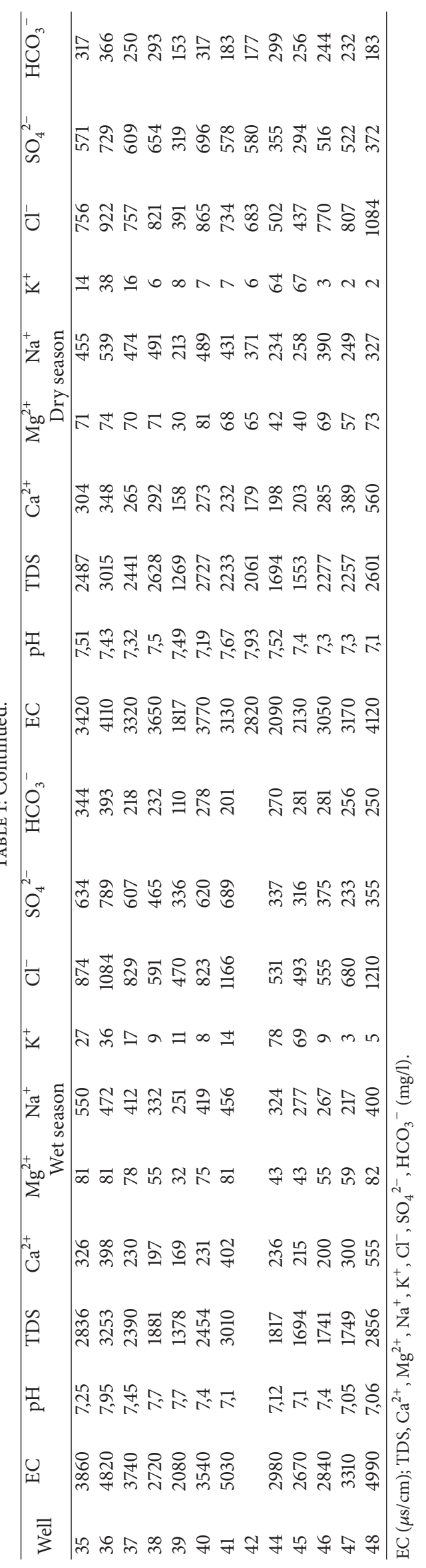




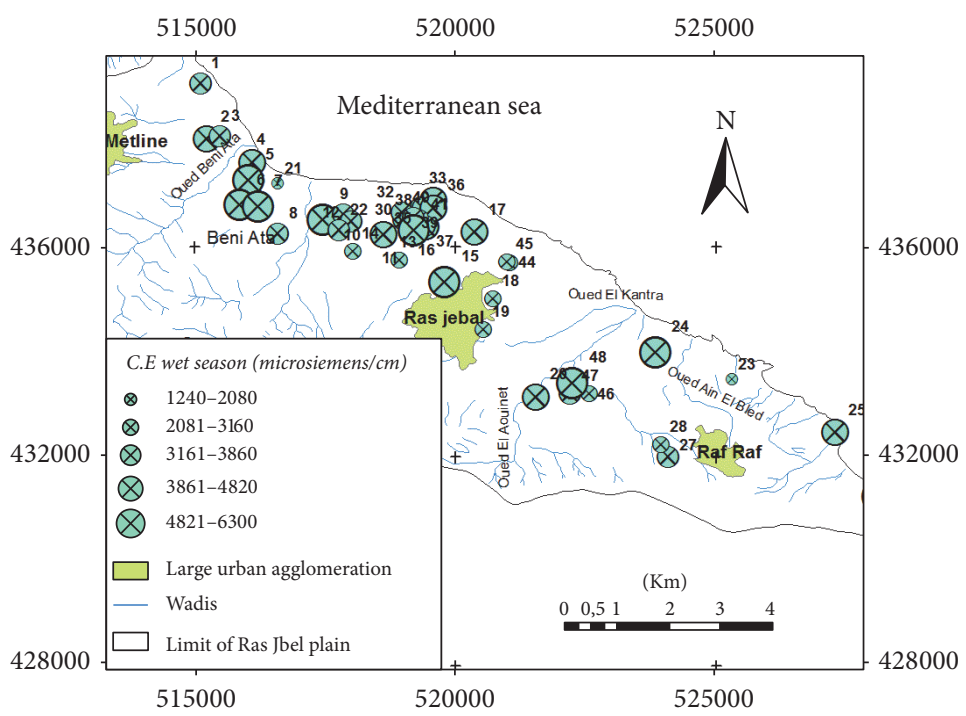

(a)

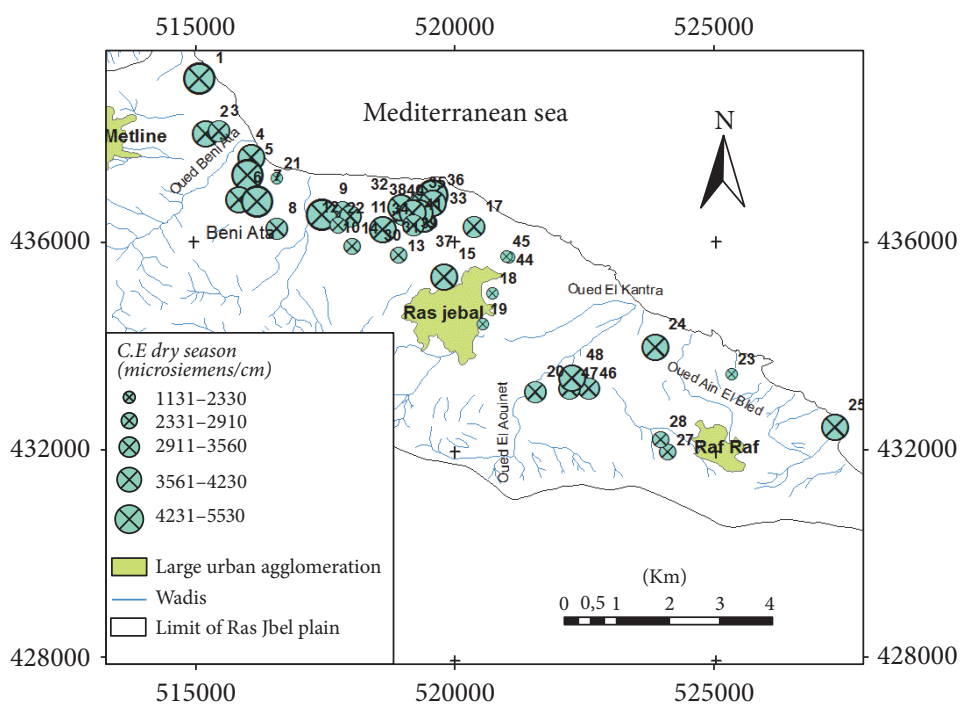

(b)

FIGURE 6: Spatial distribution of electrical conductivity (a) wet season and (b) dry season in Ras Jbel aquifer.

(EC) values of near-coastal shallow groundwater. The high EC of groundwater from wells located along the coast and in Bahirat Beni Ata can be explained by the seawater intrusion effect caused by the groundwater level drawdown due to overexploitation (Figures 6(a) and 6(b)).

Based on the conductivity values, the groundwater system could be classified into four groups: fresh water $(<500 \mu \mathrm{S} /$ $\mathrm{cm})$, marginal water $(500-1,500 \mu \mathrm{S} / \mathrm{cm})$, brackish water $(1,500-5,000 \mu \mathrm{S} / \mathrm{cm})$, and saline water $(>5,000 \mu \mathrm{S} / \mathrm{cm})$. Based on our conductivity values it is evident that groundwater in Ras Jbel aquifer is in marginal and brackish waters. Few samples are of saline water type.

The study area is characterized by a wide range of salinities. Salinity values ranged between 500 and $3600 \mathrm{mg} / \mathrm{l}$ in the wet season and between 500 and $3500 \mathrm{mg} / \mathrm{l}$ in the dry season. The higher values of EC and salinity are indicators of higher ionic concentrations, probably due to the high anthropogenic activities in the region and geological weathering conditions but also due to the intrusion of sea water into the groundwater system.

The relative content of a cation or an anion is defined as the percentage of the relative amount of that ion to the total cations or anions, respectively [39]. In the study area, the strong acid anions $\left(\mathrm{Cl}^{-}\right.$and $\left.\mathrm{SO}_{4}{ }^{2-}\right)$ exceed weak acid anions $\left(\mathrm{HCO}_{3}{ }^{-}\right.$and $\left.\mathrm{CO}_{3}{ }^{2-}\right)$. On the other hand, sodium and calcium concentrations exceed magnesium and potassium contents. The triangular diagram (Figure 7) shows that the groundwater chemistry was mainly characterized by two groups. The first group was $\mathrm{Cl}^{-}-\mathrm{Na}^{+}$type, in which $\mathrm{Na}^{+}$accounted for more than $52-65 \%$ of the total cations; the second group was $\mathrm{Cl}^{-}-\mathrm{Na}^{+} / \mathrm{Ca}^{2+}$ type, in which $\mathrm{Na}^{+}$and $\mathrm{Ca}^{2+}$ accounted for $37-48 \%$ and $36-53 \%$ of the total cations, respectively. Chemical facies in the phreatic aquifer of Ras Jbel seem to be directly related to the configuration of the ante-quaternary 


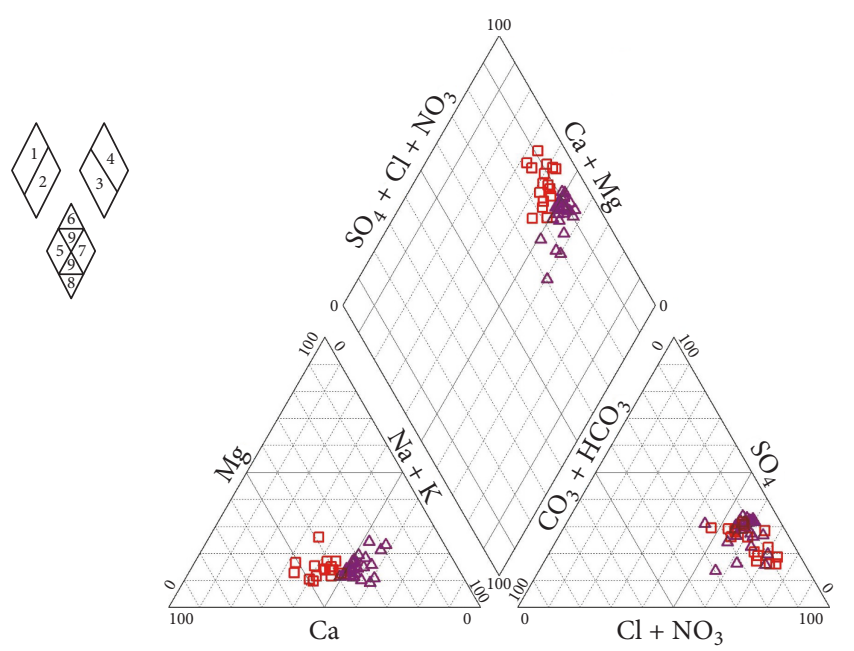

$\triangle \mathrm{NaCl}$ type

$\square \mathrm{NaCaCl}$ type

Figure 7: Piper diagram of groundwater: zone 1: alkaline earths $(\mathrm{Ca}+\mathrm{Mg})$ exceed alkalis $(\mathrm{Na}+\mathrm{K})$; zone 2 : alkalis exceed alkaline earths; zone 3: weak acids $\left(\mathrm{CO}_{3}+\mathrm{HCO}_{3}\right)$ exceed strong acids $\left(\mathrm{SO}_{4}\right.$ $+\mathrm{Cl}$ ); zone 4: strong acids exceed weak acids; zone 5: carbonate hardness > 50\% (alkaline earths and weak acid dominate); zone 6: noncarbonate hardness $>50 \%$; zone 7 : noncarbonate alkali $>50 \%$; zone 8: carbonate alkali $>50 \%$ (groundwater is inordinately soft in proportion to the content of TDS); zone 9: no cation-anion pair $>50 \%$ [34].

substratum and the proximity of several sampled wells from the sea.

The Na-Cl-type indicated the presence of high chloride concentrations in the aquifer which may originate from the dissolution of halite, influx of sewage or waste water, and mainly intrusion of sea water [40]. In the downstream part of the plain near the sea and in Bahirat Beni Ata, where a marine intrusion was detected since 1980, the groundwater is mainly of $\mathrm{Cl}^{-}-\mathrm{Na}^{+}$type (Figure 8). The distribution maps of $\mathrm{Cl}^{-}$in both wet and dry seasons (Figures 9(a) and 9(b)) are well correlated with those of electrical conductivity and facies.

4.2. Processes Controlling Groundwater Salinization. Understanding the water salinization mechanism is the basis for regional salt management. Groundwater salinization is largely a function of the mineral composition of the aquifer through which it flows and hydrogeochemical processes such as mineral dissolution, precipitation, evaporation and transpiration, ion exchange, and the residence time along the flow path. It is also linked to various anthropogenic activities such as agriculture, overexploitation of groundwater resources, and sewage disposal.

4.2.1. Water-Rock Interaction and Origin of Groundwater Mineralization. Reactions between groundwater and aquifer minerals have a significant role on water quality. The $p \times p$ correlation matrix, revealing the existence of bivariate linear correlations between variables, allows a better understanding of the dominant water-rock interactions or source of the ions over the study area. Additionally, the use of multivariate
TABle 2: Principal component matrix.

\begin{tabular}{lccc}
\hline & $F 1$ & $F 2$ & $F 3$ \\
\hline $\mathrm{CE}$ & $\mathbf{0 , 9 7}$ & $-0,03$ & 0,05 \\
$\mathrm{TDS}$ & $\mathbf{0 , 9 8}$ & $-0,04$ & 0,08 \\
$\mathrm{pH}$ & $-0,41$ & $-0,42$ & $\mathbf{0 , 7 5}$ \\
$\mathrm{Ca}^{2+}$ & $\mathbf{0 , 8 2}$ & 0,17 & $-0,10$ \\
$\mathrm{Mg}^{2+}$ & $\mathbf{0 , 7 8}$ & 0,13 & 0,02 \\
$\mathrm{Na}^{+}$ & $\mathbf{0 , 8 9}$ & $-0,20$ & 0,17 \\
$\mathrm{~K}^{+}$ & $-0,11$ & $-\mathbf{0 , 8 6}$ & $-0,16$ \\
$\mathrm{Cl}^{-}$ & $\mathbf{0 , 9 6}$ & 0,14 & 0,07 \\
$\mathrm{SO}_{4}{ }^{2-}$ & $\mathbf{0 , 7 7}$ & $-0,20$ & 0,28 \\
$\mathrm{HCO}_{3}{ }^{-}$ & 0,43 & $-\mathbf{0 , 5 7}$ & $-0,49$ \\
Eigenvalue & 5,86 & 1,40 & 0,95 \\
\% Explication & 58,64 & 14 & 9,53 \\
\% Cumulative & $\mathbf{5 8 , 6 4}$ & $\mathbf{7 2 , 6 4}$ & $\mathbf{8 2 , 1 7}$ \\
\hline
\end{tabular}

Bold values: loadings $\geq 0.5$.

statistics in hydr(geo)logical studies is a very common practice and numerous applications can be found in the literature $([10,19,41])$ though most hydrologists consider that values larger than 0.5 indicate significant correlation. In the present study, PCA was carried out for 10 parameters $(\mathrm{Ca}, \mathrm{Mg}$, $\mathrm{Na}, \mathrm{K}, \mathrm{HCO}_{3}, \mathrm{SO}_{4}, \mathrm{Cl}, \mathrm{pH}$, TDS, and EC) and more than 90 observations (Tables 2 and 3 ). The first two factors $F 1$ and F2 were always retained, explaining about $73 \%$ of the total variance (Table 2). Factors of a higher order generally explained the variance of a single parameter or established poorer and less significant correlations with two parameters [42].

The correlations established between the TDS and concentrations of major elements (Table 3 ) show that the TDS is well correlated with the concentrations of chloride $\left(r^{2}=\right.$ $0,96)$, sodium $\left(r^{2}=0,87\right)$, calcium $\left(r^{2}=0,83\right)$, magnesium $\left(r^{2}=0,73\right)$, and sulphates $\left(r^{2}=0,76\right)$. The high correlation of TDS with chloride, sodium, magnesium, sulphate, and calcium indicated that these elements are mostly contributed by mineralization. These ions have been dissolved into groundwater continuously and resulted in the rise of TDS. The contribution of carbonates and potassium is negligible $\left(r^{2}=\right.$ 0,37 and $r^{2}=-0,05$, resp.). The low correlation between TDS and $\mathrm{pH}$ suggests that the dissolution of the salts is not related to acidic conditions of groundwater but it is related to their degrees of solubility. $\mathrm{HCO}_{3}{ }^{-}$and $\mathrm{pH}$ apparently have little association with the other variables.

Bicarbonates are not correlated to calcium $r\left(\mathrm{HCO}_{3} \mathrm{Ca}\right)$ $=0,20$ indicating another source other than the calcite dissolution. However, considerable correlation coefficients between sodium and chlorides $r(\mathrm{NaCl})=0,84$ and between calcium and sulphates $r\left(\mathrm{CaSO}_{4}\right)=0,50$ suggest halite and gypsum dissolution, respectively.

The first factor $F 1$ accounts for $58 \%$ of the total variance, and it is contributed by the following variables: EC, TDS, $\mathrm{Mg}$, $\mathrm{Ca}, \mathrm{Na}, \mathrm{Cl}$, and $\mathrm{SO}_{4}$. This factor is associated with the salinity component ( $\mathrm{NaCl}$ salt source with $\mathrm{Ca}$ and $\mathrm{SO}_{4}$ enrichment) and the cation exchange. The second factor $\mathrm{F} 2$ accounts for $14 \%$ of the total variance, and it is negatively determined by $\mathrm{K}$ 
TABLE 3: Correlation matrix of dissolved species and the TDS for the study area in wet season.

\begin{tabular}{|c|c|c|c|c|c|c|c|c|c|c|}
\hline & $\mathrm{CE}$ & TDS & $\mathrm{pH}$ & $\mathrm{Ca}^{2+}$ & $\mathrm{Mg}^{2+}$ & $\mathrm{Na}^{+}$ & $\mathrm{K}^{+}$ & $\mathrm{Cl}^{-}$ & $\mathrm{SO}_{4}{ }^{2-}$ & $\mathrm{HCO}_{3}^{-}$ \\
\hline $\mathrm{CE}$ & 1 & & & & & & & & & \\
\hline TDS & 0,98 & 1 & & & & & & & & \\
\hline $\mathrm{pH}$ & $-0,34$ & $-0,32$ & 1 & & & & & & & \\
\hline $\mathrm{Ca}^{2+}$ & 0,84 & 0,83 & $-0,44$ & 1 & & & & & & \\
\hline $\mathrm{Mg}^{2+}$ & 0,73 & 0,73 & $-0,30$ & 0,43 & 1 & & & & & \\
\hline $\mathrm{Na}^{+}$ & 0,84 & 0,87 & $-0,18$ & 0,60 & 0,65 & 1 & & & & \\
\hline $\mathrm{K}^{+}$ & $-0,04$ & $-0,05$ & 0,23 & $-0,11$ & $-0,28$ & 0,01 & 1 & & & \\
\hline $\mathrm{Cl}^{-}$ & 0,95 & 0,96 & $-0,37$ & 0,84 & 0,76 & 0,84 & $-0,19$ & 1 & & \\
\hline $\mathrm{SO}_{4}{ }^{2-}$ & 0,73 & 0,76 & $-0,12$ & 0,50 & 0,52 & 0,75 & $-0,02$ & 0,65 & 1 & \\
\hline $\mathrm{HCO}_{3}{ }^{-}$ & 0,36 & 0,37 & $-0,20$ & 0,20 & 0,37 & 0,42 & 0,30 & 0,27 & 0,32 & 1 \\
\hline
\end{tabular}

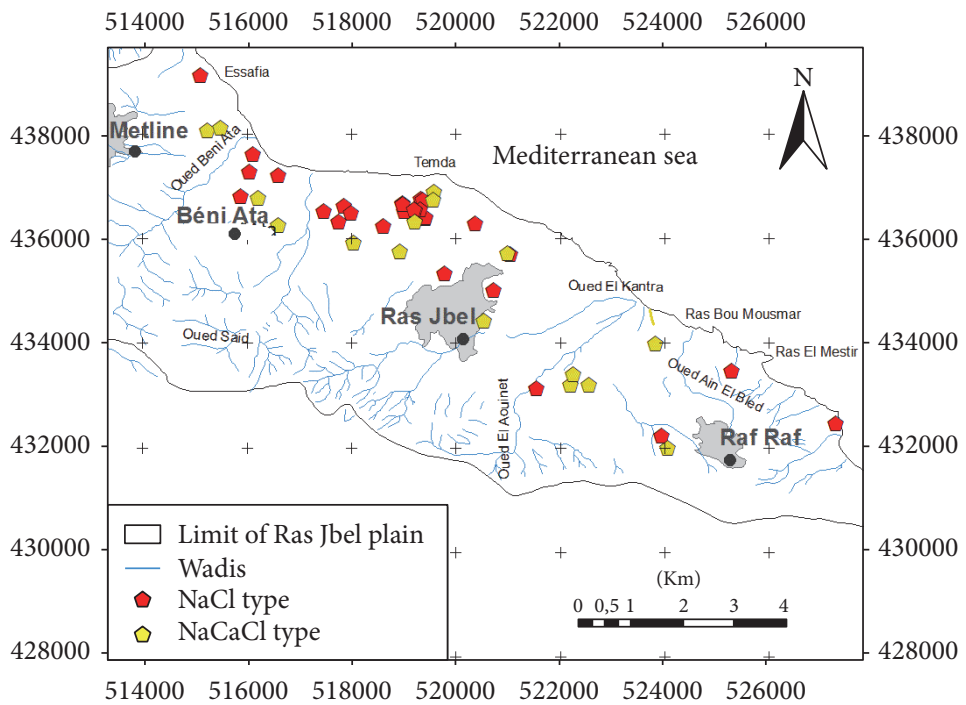

FIGURE 8: Distribution map of the groundwater facies in the shallow aquifer of Ras Jbel.

and $\mathrm{HCO}_{3}$ (Figure 10). It suggests carbonates weathering and pollution by fertilizer application.

In order to understand the origin of groundwater mineralization in Ras Jbel plain, the saturation index (SI) was calculated. The mineral facies are chosen based on the analysis result of groundwater quality, the main components of groundwater, and the occurrences conditions ([6, 43,44]). In the study area, the main cations are $\mathrm{Na}^{+}, \mathrm{Ca}^{2+}$, and $\mathrm{Mg}^{2+}$ and the main anions are $\mathrm{HCO}_{3}{ }^{-}, \mathrm{SO}_{4}{ }^{2-}$, and $\mathrm{Cl}^{-}$; thus gypsum, anhydrite, calcite, dolomite, aragonite, and halite are chosen to be the mineral facies.

The positive values of the calculated SI with respect to calcite and dolomite for all groundwater samples (Figure 11) suggest their oversaturation in respect to these minerals $\left(0,05<\mathrm{SI}_{\text {calcite }}<1,32\right.$ and $0,08<\mathrm{SI}_{\text {calcite }}<1,18$ in the wet and dry seasons, resp., and $-0,10<\mathrm{SI}_{\text {dolomite }}<2,29$ and $0,06<\mathrm{SI}_{\text {dolomite }}<1,98$ in the wet and dry seasons, resp.). As described by Appelo and Postma [45], the dissolution of calcite and dolomite is as follows:

Calcite:

$$
\mathrm{CaCO}_{3}+\mathrm{CO}_{2}+\mathrm{H}_{2} \mathrm{O} \longleftrightarrow \mathrm{Ca}^{2+}+2 \mathrm{HCO}_{3}^{-}
$$

Dolomite:

$$
\begin{gathered}
\mathrm{CaMg}\left(\mathrm{CO}_{3}\right)_{2}+2 \mathrm{CO}_{2}+2 \mathrm{H}_{2} \mathrm{O} \\
\longleftrightarrow \mathrm{Ca}^{2+}+\mathrm{Mg}^{2+}+4 \mathrm{HCO}_{3}{ }^{-}
\end{gathered}
$$

However, focusing on the scatter plots of bicarbonate versus calcium and calcium + magnesium versus bicarbonate we notice that groundwater samples are not plotted on the 1:1 straight lines of calcite and dolomite dissolution (Figures 12(a) and 12(b)). Groundwater samples show an excess of $\mathrm{Ca}^{2+}$ that can be explained by the gypsum dissolution.

The plot of SIGypsum and SIAnhydrite versus TDS exhibits a proportional and parabolic shape evolution with negative values of the saturation indexes (Figure 11) $(-1,86<$ $\mathrm{SI}_{\text {gypsum }}<-0,34$ and $-1,72<\mathrm{SI}_{\text {gypsum }}<-0,35$ in the wet and dry seasons, resp., and $-2,08<\mathrm{SI}_{\text {anhydrite }}<-0,56$ and $-1,94<\mathrm{SI}_{\text {anhydrite }}<-0,56$ in the wet and dry seasons, resp.). Thus, both calcium and sulphate are derived from the same origin, which is the dissolution of gypsum and anhydrite.

$$
\text { Gypsum: } \mathrm{CaSO}_{4} \cdot 2 \mathrm{H}_{2} \mathrm{O} \longleftrightarrow \mathrm{Ca}^{2+}+\mathrm{SO}_{4}{ }^{2-}+2 \mathrm{H}_{2} \mathrm{O}
$$




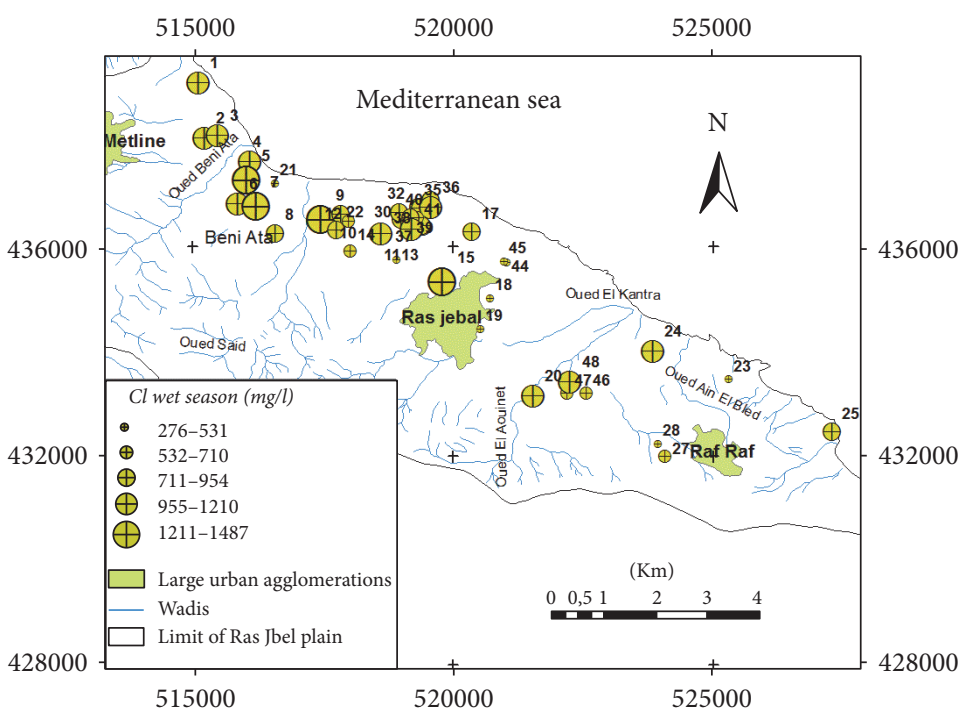

(a)

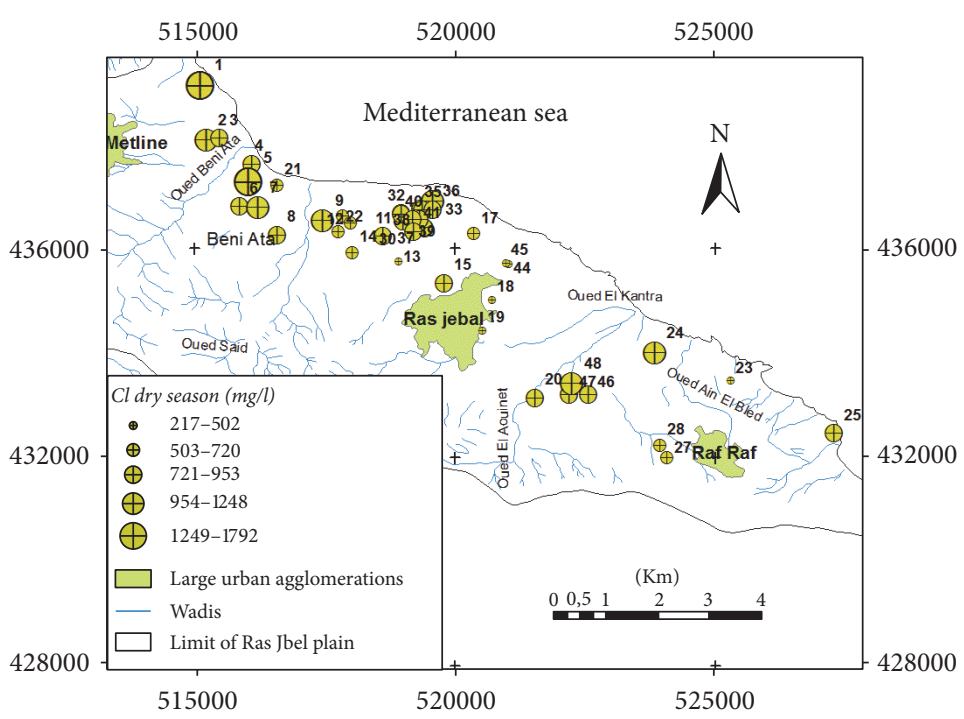

(b)

FIgURE 9: Spatial distribution of chlorides (a) wet season and (b) dry season in Ras Jbel aquifer.

However, the plot of sulphate versus calcium (Figure 12(c)) shows an excess of $\mathrm{Ca}^{2+}$ ions for the majority of the groundwater samples. For these samples, the $\left(\mathrm{Ca} /\left(\mathrm{Ca}+\mathrm{SO}_{4}\right)\right)$ ionic ratio greater than 0,5 ratio (from 0,53 and 0,79 ) confirms the ionic exchange process [46]. The $\left(\mathrm{Ca} /\left(\mathrm{Ca}+\mathrm{SO}_{4}\right)\right)$ ionic ratio close to 0,5 confirms that the main source of $\mathrm{Ca}^{2+}$ is the gypsum dissolution [46].

A bivariate diagram of sodium versus chloride (Figure $12(\mathrm{~d})$ ) reveals two main groups: for the first group halite dissolution was maintained for a slope equal to unity where majority of the samples are situated on the 1:1 straight of halite dissolution given by the following reactions [45]:

$$
\text { Halite: } \mathrm{NaCl} \longleftrightarrow \mathrm{Na}^{+}+\mathrm{Cl}^{-}
$$

The second group includes the high-salinity samples $(\mathrm{Na}-\mathrm{Cl}$ type), which do not follow the halite dissolution line and show enrichment in chloride compared to sodium. Thus, another phenomenon other than geological effect is controlling their salinization, and this may be the salt water intrusion.

Water samples were plotted in the Gibbs diagrams, which takes into account the major role of natural mechanisms (rock weathering, evaporation, and precipitation). Figure 13 clearly shows that the mechanism controlling water chemistry seems to be a combination of the weathering of carbonates minerals as well as the evaporation-precipitation processes. However, low rates of the groundwater samples were obtained in areas that were dominated by rock-water interactions.

Samples with $\mathrm{Na}^{+} /\left(\mathrm{Na}^{+}+\mathrm{Ca}^{2+}\right)$ or $\mathrm{Cl}^{-} /\left(\mathrm{Cl}^{-}+\mathrm{HCO}_{3}{ }^{-}\right)$ ratios greater than 0,5 and TDS levels between 783 and $4323 \mathrm{mg} / \mathrm{l}$ showed that the groundwater chemistry was controlled mainly by the saline water mixing or evaporation. Evaporation results in increased TDS in relation to high ratios 

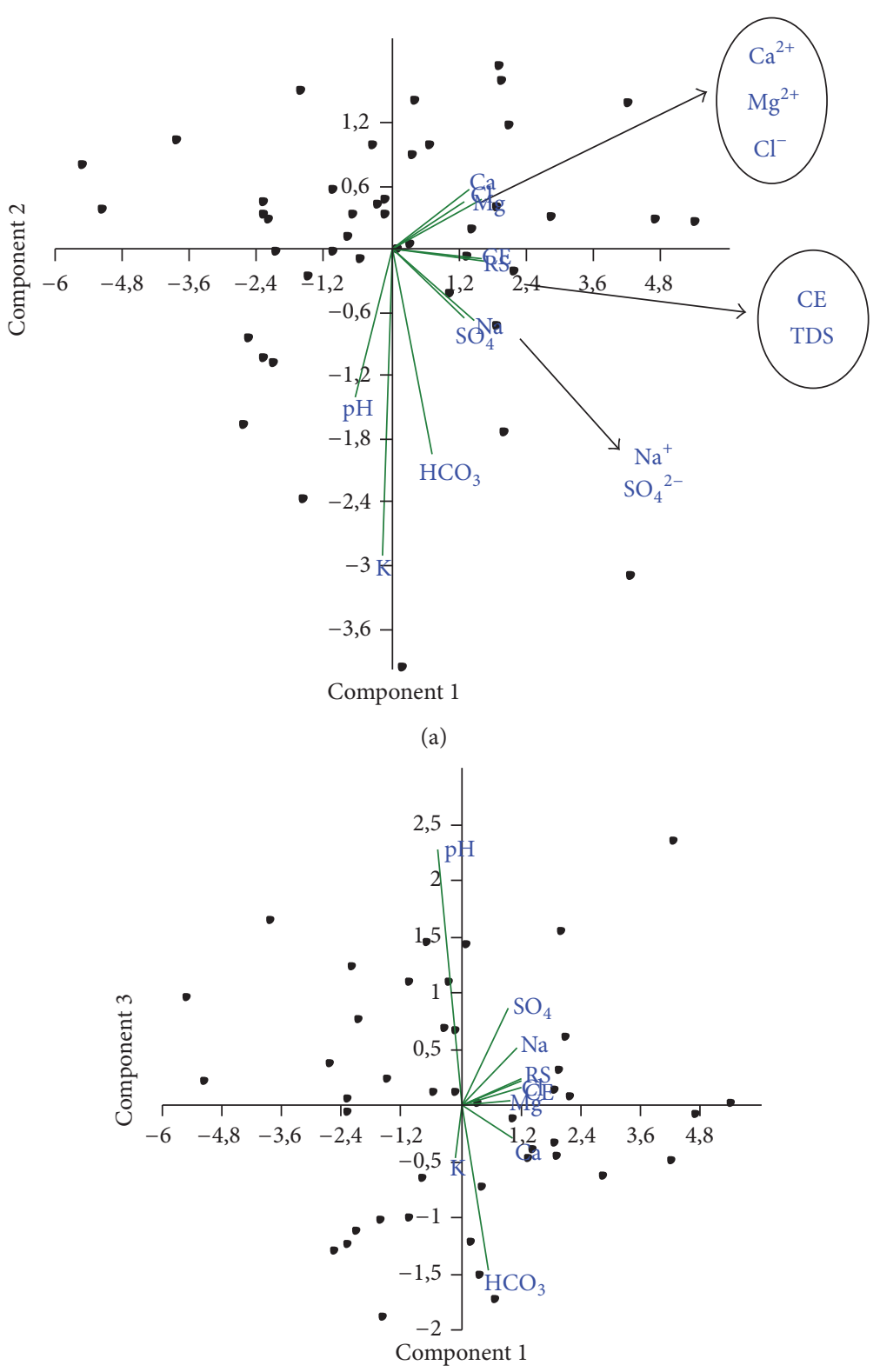

(b)

FIGURE 10: Representation of variables into two principal factors: $F 1-F 2$ (a) and $F 1-F 3$ (b).

of dominant cations and anions and $\mathrm{CaCO}_{3}$ precipitates by losing $\mathrm{Ca}^{2+}$ and $\mathrm{HCO}_{3}{ }^{-}$.

4.2.2. Ionic Exchange Processes and Freshwater-Saline Water Mixing. Ion exchange is one of the important natural processes responsible for the concentration of ions in groundwater and has significant impact on the evolution of groundwater chemistry [18]. The dominance of salty groundwater dominated by sodium and chloride ions in Ras Jbel shallow aquifer provides evidence of mixing with an external salinity source, which could be the seawater from the coastal part of the aquifer. Cation exchange, responsible for the salinity signature, is described by two mixing mechanisms (freshening and saline water intrusion). Equations (6) and (7) show the gain or loss related to $\mathrm{Na}^{+}$and $\left(\mathrm{Ca}^{2+}+\mathrm{Mg}^{2+}\right)$ within the exchanger $\mathrm{X}$.

The freshening process or direct ion exchange: where $\mathrm{Ca}^{2+}$ from freshwater displaced the marine cations $\mathrm{Na}^{+}$and $\mathrm{Mg}^{2+}$ from the exchanger complex. The resulting loss of $\mathrm{Ca}^{2+}$ from solution decreases the saturation state for calcite and possibly causes calcite dissolution.

$$
\frac{1}{2} \mathrm{Ca}^{2+}+\mathrm{Na}-\mathrm{X} \longrightarrow \mathrm{Na}^{+}+\frac{1}{2} \mathrm{Ca}-\mathrm{X}
$$

The intrusion of seawater or reverse ion exchange also triggered cation exchange reactions where $\mathrm{Ca}^{2+}$ was expelled from the exchanger by seawater $\mathrm{Na}^{+}$and $\mathrm{Mg}^{2+}$. The released 

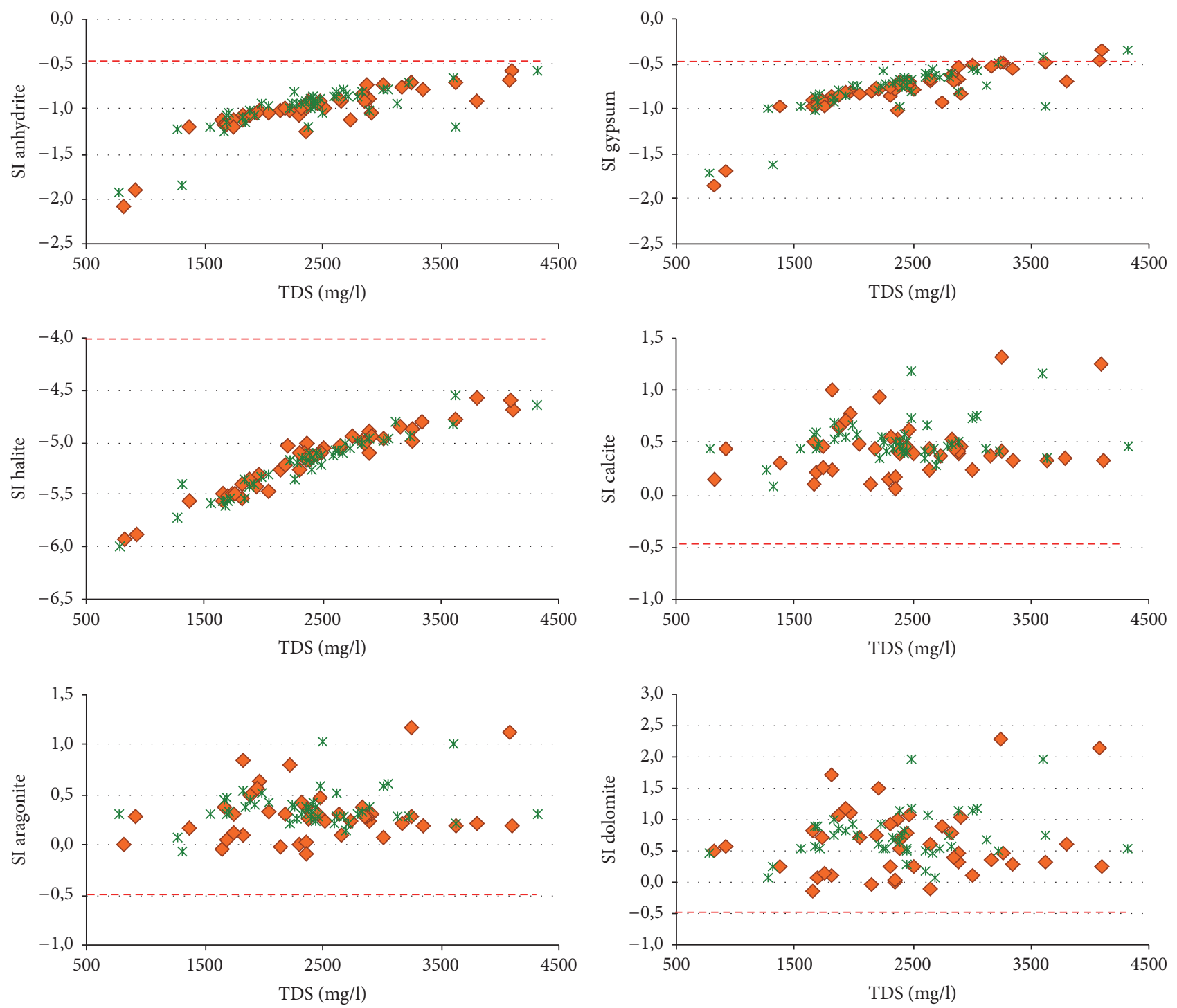

FIGURE 11: Variation of saturation indices of selected minerals in wet and dry seasons.

$\mathrm{Ca}^{2+}$ is being flushed from the aquifer by groundwater flow $[45,47]$.

$$
\frac{1}{2} \mathrm{Na}^{+}+\mathrm{Ca}-\mathrm{X} \longrightarrow \mathrm{Ca}^{2+}+\frac{1}{2} \mathrm{Na}-\mathrm{X}
$$

The plot of $\left[\left(\mathrm{Ca}^{2+}+\mathrm{Mg}^{2+}\right)-\left(\mathrm{HCO}_{3}{ }^{-}+\mathrm{SO}_{4}{ }^{2-}\right)\right]$ versus $\left(\mathrm{Na}^{+}-\mathrm{Cl}^{-}\right)$determines the exchange of $\mathrm{Na}^{+}$against $\left(\mathrm{Ca}^{2+}\right.$ or $\left.\mathrm{Mg}^{2+}\right)$ through the clay matrix. The relationship $\left[\left(\mathrm{Ca}^{2+}+\right.\right.$ $\left.\left.\mathrm{Mg}^{2+}\right)-\left(\mathrm{HCO}_{3}{ }^{-}+\mathrm{SO}_{4}{ }^{2-}\right)\right]$ is the gain or loss of $\left(\mathrm{Ca}^{2+}+\mathrm{Mg}^{2+}\right)$ due to the carbonates and gypsum dissolution. The relationship of $\left(\mathrm{Na}^{+}-\mathrm{Cl}^{-}\right)$determines the gain or loss of $\mathrm{Na}^{+}$relative to the halite dissolution. If there is no ion exchange, all water samples will be placed in the origin of diagram [46].

Figure 14 shows that reverse ion exchange is a dominant process. To confirm the effect of reverse ion exchange, chloroalkaline index CAI-1 was calculated in milliequivalents per liter according to the relationship proposed by Schoeller [48]:

$$
\mathrm{CAI}-1=\frac{\left[\mathrm{Cl}^{-}-\left(\mathrm{Na}^{+}+\mathrm{K}^{+}\right)\right]}{\mathrm{Cl}^{-}}
$$

If reverse ion exchange occurs in groundwater, CAI-1 values are positive. The calculated CAI-1 values are positive for more than $70 \%$ of the water samples which confirmed that reverse ion exchange is a dominant process. This shows that the interaction between the seawater and groundwater in the study area is playing a major role in the contamination of the aquifer by seawater intrusion. These results indicate that seawater/freshwater interface is in a continuous evolution despite the artificial recharge operations since 1993, and this probably because of the permanent heavy pumping. 


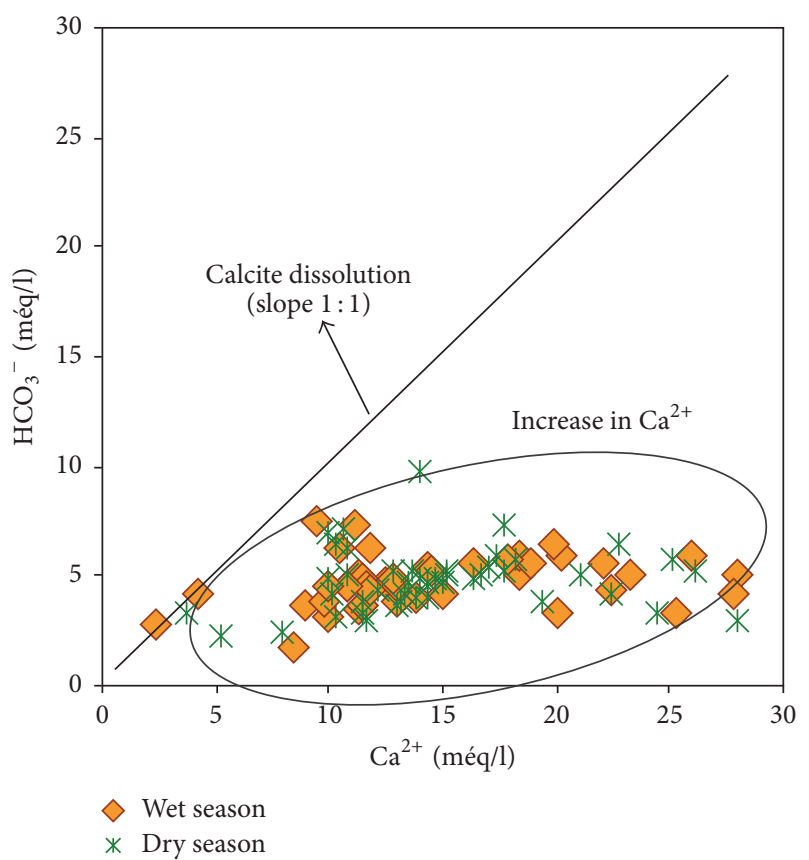

(a)

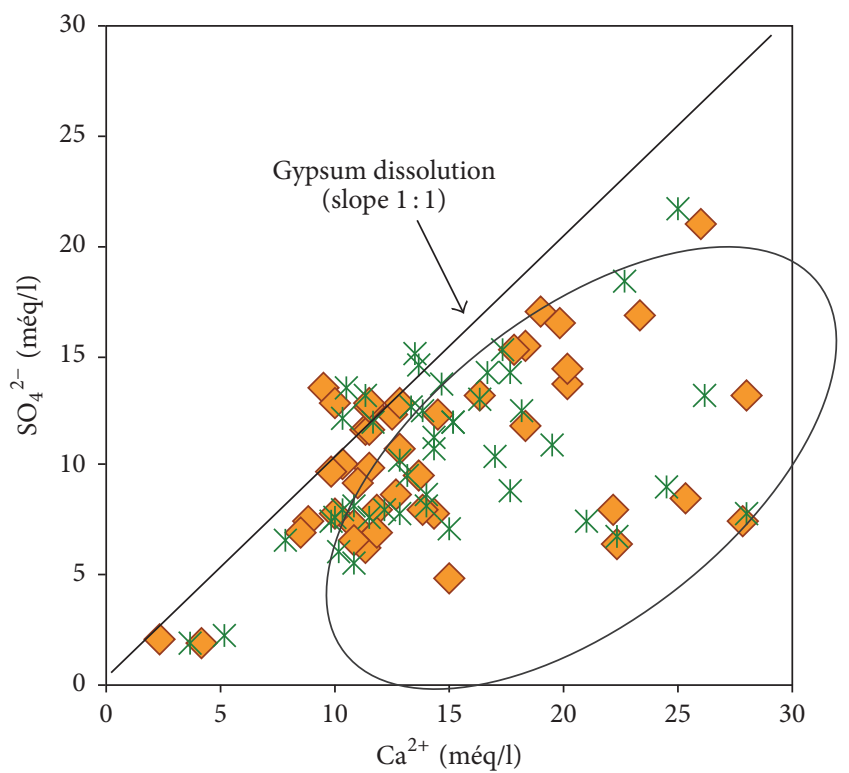

$\diamond$ Wet season
$*$ Dry season

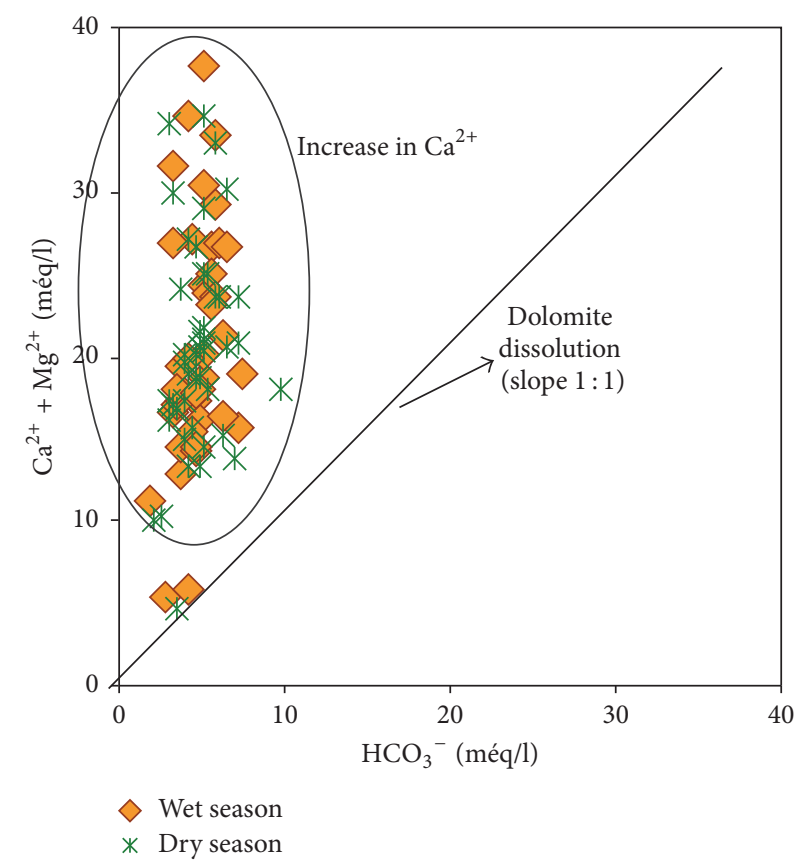

(b)

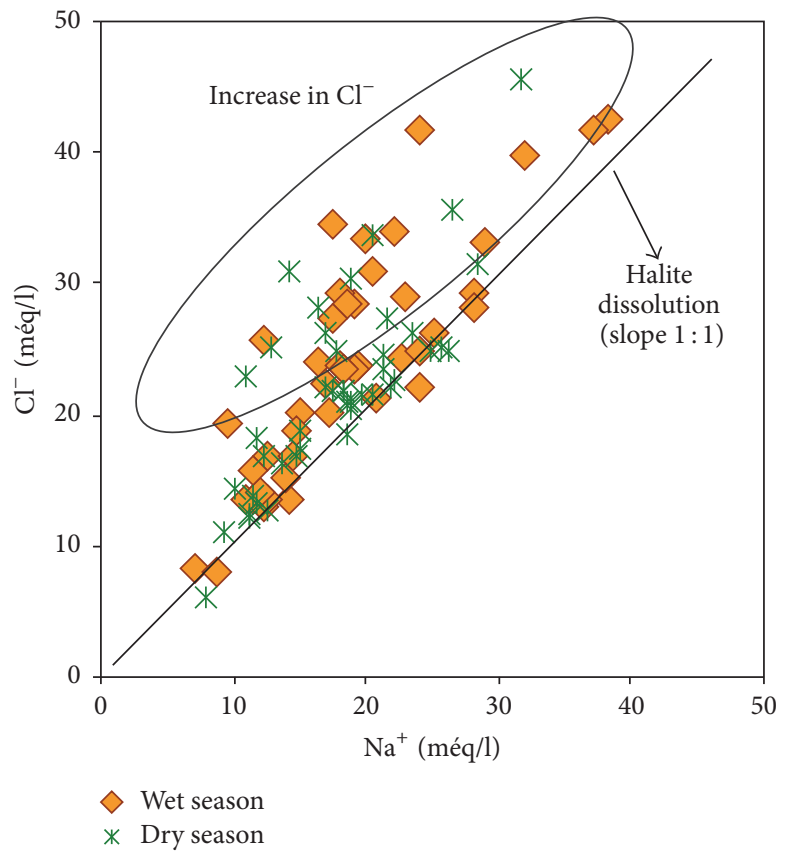

(d)

FIGURE 12: Water-rock interaction: relationships between different solutes of $\mathrm{Na}^{+}, \mathrm{Ca}^{2+}, \mathrm{Mg}^{2+}, \mathrm{Cl}^{-}, \mathrm{SO}_{4}{ }^{2-}$, and $\mathrm{HCO}_{3}{ }^{-}(\mathrm{a}, \mathrm{b}, \mathrm{c}, \mathrm{d})$.

Water samples concentrated in the origin of the plot $\left[\left(\mathrm{Ca}^{2+}+\mathrm{Mg}^{2+}\right)-\left(\mathrm{HCO}_{3}{ }^{-}+\mathrm{SO}_{4}{ }^{2-}\right)\right]$ versus $\left(\mathrm{Na}^{+}-\mathrm{Cl}^{-}\right)$indicated the absence of the ion exchange process which can be attributed to the evaporation process followed by carbonate precipitation [49]. This result confirmed the results obtained using saturation states of minerals and Gibbs diagrams.

The seawater fraction in the groundwater is often estimated using chloride concentration [50]. Chloride ion has been considered as a conservative tracer not affected by ion exchange [51]. For conservative mass balance of the mixture, the equation used is as follows [45]:

$$
f=\frac{\left(\mathrm{Cl}_{\text {mix }}-\mathrm{Cl}_{\text {freshwater }}\right)}{\left(\mathrm{Cl}_{\text {seawater }}-\mathrm{Cl}_{\text {freshwater }}\right)} \times 100,
$$

where $\mathrm{Cl}_{\text {mix }}$ is the $\mathrm{Cl}^{-}$concentration of the sample, $\mathrm{Cl}_{\text {seawater }}$ is the $\mathrm{Cl}^{-}$concentration of the Mediterranean Sea, and 


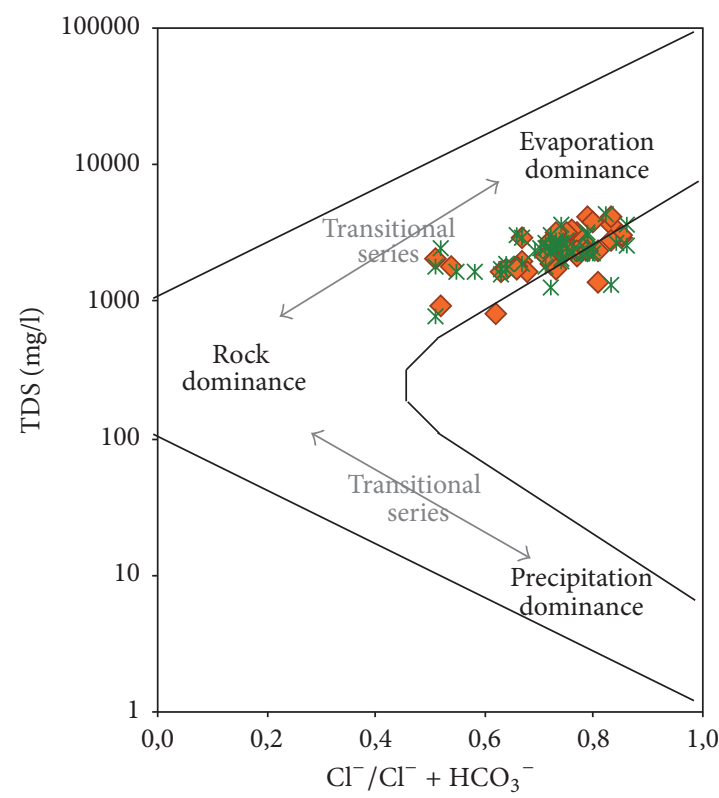

(a)

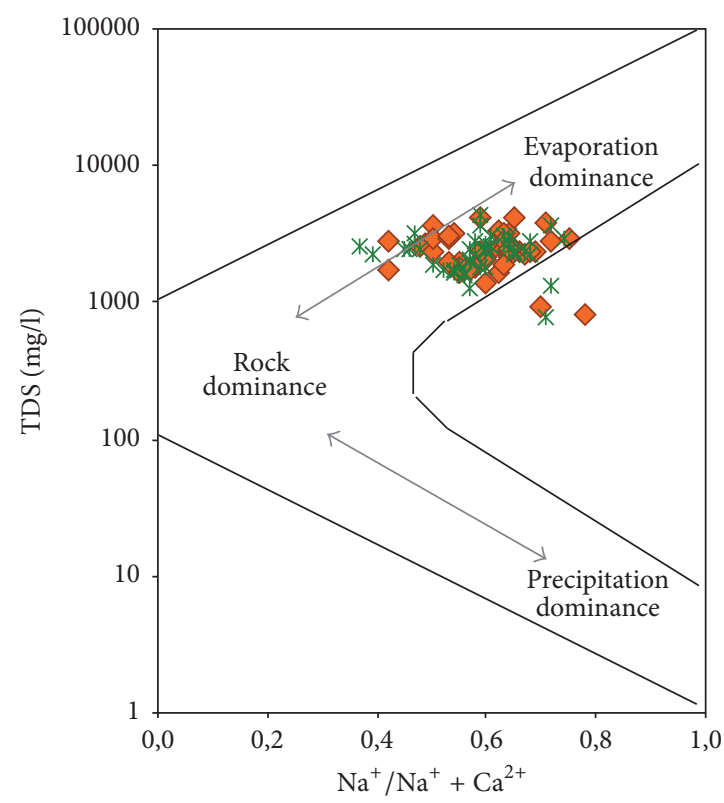

(b)

FIGURE 13: Gibbs diagram showing TDS versus (a) $\mathrm{Na} /\left(\mathrm{Na}+\mathrm{Ca}\right.$ ) and (b) $\mathrm{Cl} /\left(\mathrm{Cl}+\mathrm{HCO}_{3}\right)$.

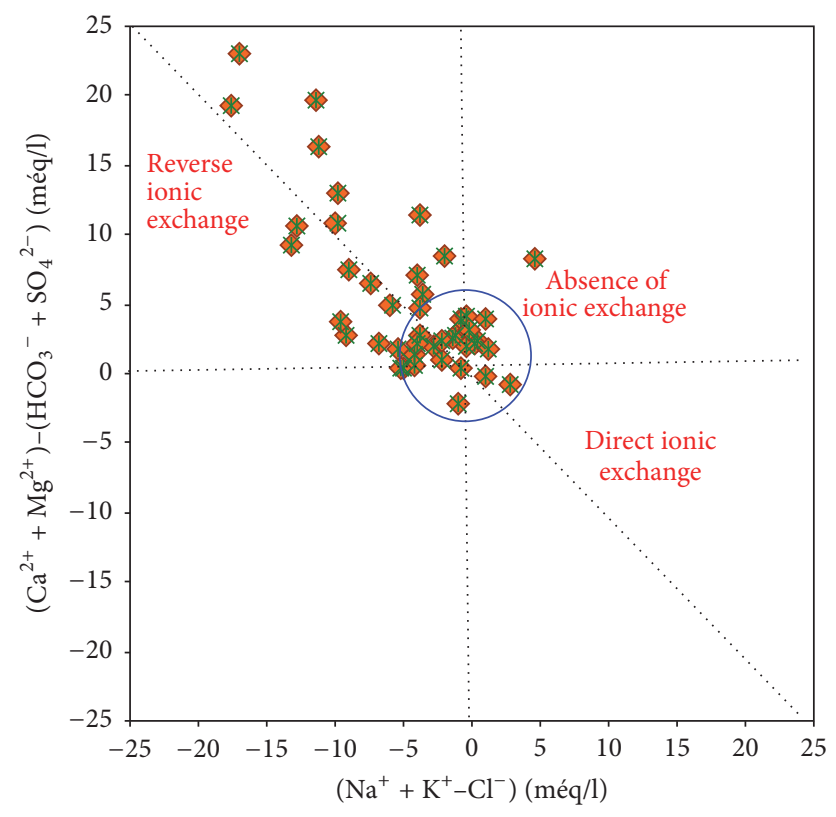

FIgURE 14: Plot of $\left[\left(\mathrm{Ca}^{2+}+\mathrm{Mg}^{2+}\right)-\left(\mathrm{HCO}_{3}{ }^{-}+\mathrm{SO}_{4}{ }^{2-}\right)\right]$ versus $\left(\mathrm{Na}^{+}+\right.$ $\mathrm{K}^{+}-\mathrm{Cl}^{-}$) for ion exchange.

$\mathrm{Cl}_{\text {freshwater }}$ represents the $\mathrm{Cl}^{-}$concentration of the fresh water. The fresh water sample will be chosen considering the lowest measured value of the electrical conductivity.

The rate of mixture varies from $0,32 \%$ (well $n^{\circ} 23$ ) in the north of the Raf Raf region and where the configuration of the ante-quaternary substratum prevents the marine intrusion to $13 \%$ (well $\mathrm{n}^{\circ} 1$ ) near the shoreline (close to the coast). The highest value of the mixing fraction corresponds to the highest measured values of $\mathrm{Cl}^{-}$and EC $(1792 \mathrm{mg} / \mathrm{l}$ and $5430 \mu \mathrm{S} / \mathrm{cm}$, resp.).
4.3. Isotopes and Groundwater Origin. The stable isotope ratios of oxygen and hydrogen in the groundwater are useful tools to differentiate between salinity origins $[52,53]$ and to help us understand various sources of recharge processes to groundwater because they are sensitive to physical processes such as atmospheric circulation, groundwater mixing, and evaporation $([33,54])$.

In arid and semiarid regions evaporation could be an important process influencing groundwater chemistry [19]. To understand the relationship between isotopic composition of groundwater of the shallow aquifer of Ras Jbel and those of precipitation measured at the station of Tunis Carthage situated at $50 \mathrm{~km}$ from the plain of Metline-Ras Jbel- Raf Raf, a bivariate diagram $\delta^{2} \mathrm{H}$ versus $\delta^{18} \mathrm{O}$ is plotted in Figure 15(a).

A local meteoric water line (LMWL) for Tunis Carthage was used to interpret the data in this study. The local meteoric water line (LMWL) is controlled by local hydrometeorological factors, including the origin of the vapor mass, reevaporation during rainfall, and the seasonality of precipitation [33]. The isotope composition of the precipitation was plotted along the LMWL using the following equation: $\delta^{2} \mathrm{H}(\%)=$ $8 * \delta^{18} \mathrm{O}(\% \mathrm{o})+12,4$ (which had a correlation coefficient $\left.R^{2}=0,99\right)[55,56]$.

Figure 15(a) shows that the isotopic composition of most of the groundwater samples collected in the wet season (except for sampling site number 35) lies within a narrow range, confirming that these groundwater samples had the same recharge source. Furthermore, all groundwater samples are scattered around the LMWL indicating that the recharge of the Ras Jbel shallow aquifer originates from infiltration of recent precipitation from Mediterranean vapor masses. Based on their isotopic composition, two groups of groundwater samples were identified (Table 4). The first group is relatively depleted in isotopic values and includes samples with $\delta^{18} \mathrm{O}$ 


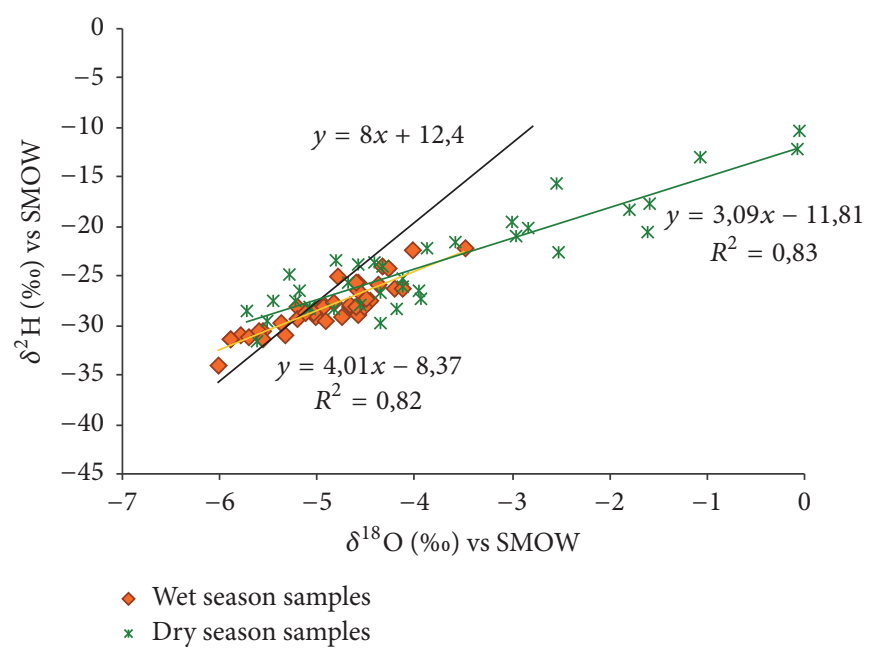

(a)

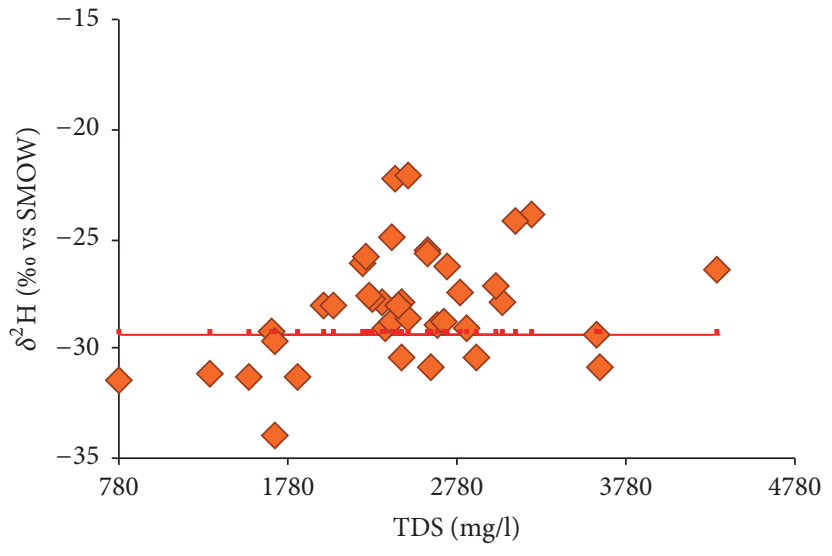

(b)

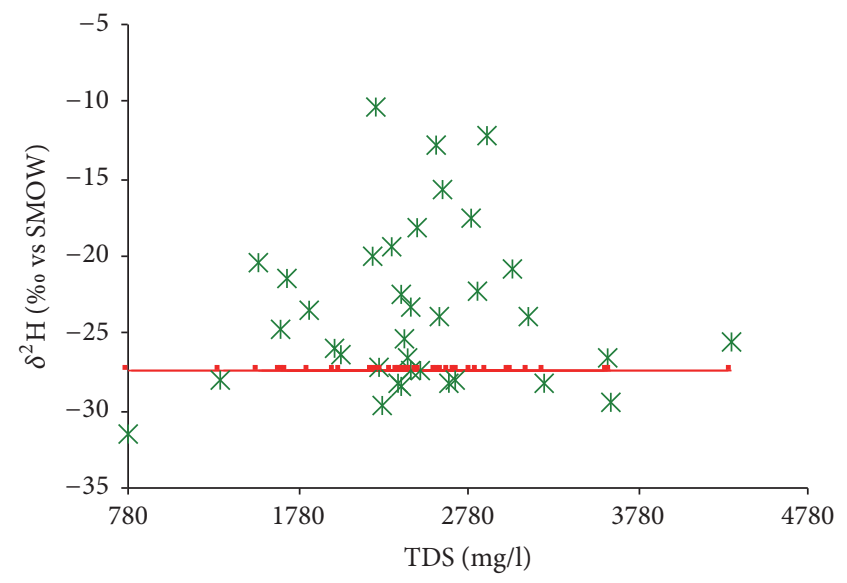

(d)

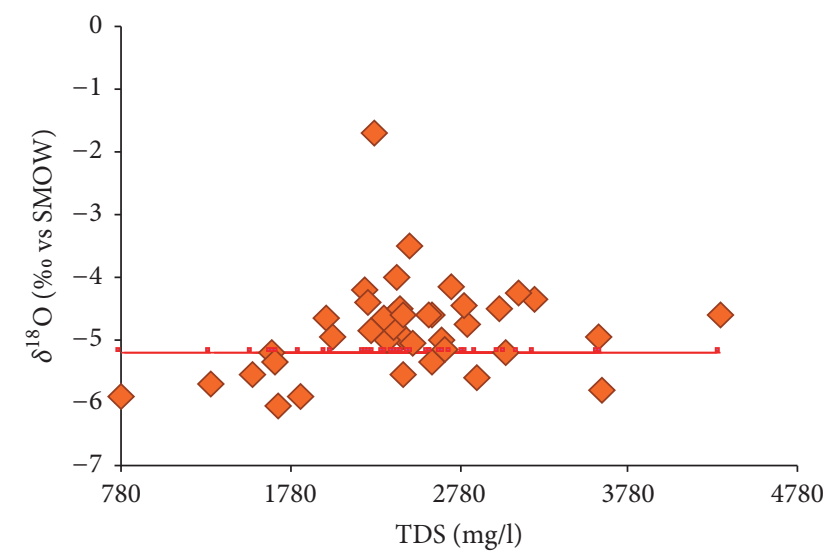

(c)

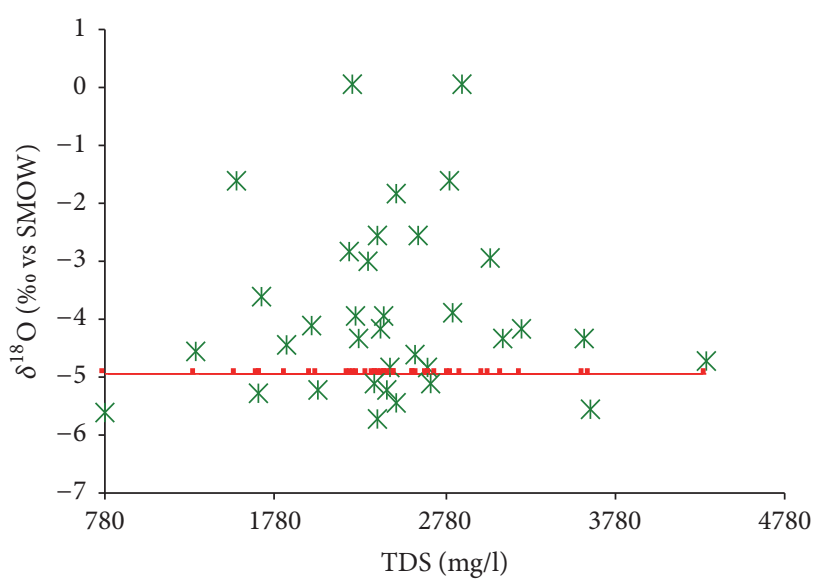

(e)

FIGURE 15: Isotopic relationships of groundwater in the study area.

and $\delta^{2} \mathrm{H}$ values ranging from $-6,03$ to $-5,37 \%$ versus $\mathrm{V}$ SMOW and from $-33,94$ to $-29,66 \%$ versus V-SMOW, respectively. This may be explained by the fact that nonevaporated water is rapidly infiltrated to the saturated zone.

As per the second group, values vary from $-5,35$ to $-3,50 \%$ versus $\mathrm{V}-\mathrm{SMOW}$ and from $-29,37$ to $-22,15 \%$ o versus
$\mathrm{V}$-SMOW, for $\delta^{18} \mathrm{O}$ and $\delta^{2} \mathrm{H}$, respectively. The relatively enriched isotopic values of the group 2 samples demonstrate that this groundwater is affected by evaporated open water or soil water.

The groundwater samples collected in the dry season were enriched compared to those collected in the wet season. The 
TABLE 4: Isotopic data of sampled wells and piezometers in Ras Jbel aquifer.

\begin{tabular}{|c|c|c|c|c|}
\hline \multirow{2}{*}{ Parameters } & $\delta^{18} \mathrm{O}(\%$ versus SMOW) & $\delta^{2} \mathrm{H}(\%$ versus SMOW) & $\delta^{18} \mathrm{O}(\%$ versus SMOW $)$ & $\delta^{2} \mathrm{H}(\%$ versus SMOW $)$ \\
\hline & \multicolumn{2}{|c|}{ Wet season } & \multicolumn{2}{|c|}{ Dry season } \\
\hline Minimum & $-6,03$ & $-33,94$ & $-5,74$ & $-31,46$ \\
\hline Maximum & $-3,5$ & $-22,15$ & $-0,06$ & $-10,31$ \\
\hline Average & $-4,91$ & $-28,06$ & $-3,78$ & $-23,33$ \\
\hline
\end{tabular}

results show isotopic content ranging from $-5,74$ to $-0,06 \%$ o versus V-SMOW for $\delta^{18} \mathrm{O}$ and from $-31,46$ to $-10,31 \%$ versus $\mathrm{V}$-SMOW for $\delta^{2} \mathrm{H}$. This may be explained by heavy isotope enrichment in the groundwater caused by strong evaporation given that there was effectively no precipitation in the study area between the two sampling periods; meanwhile, the groundwater may have been mainly recharged by lateral inflow from outside the study area, resulting in seasonal fluctuations in the isotopic values. The enriched groundwater samples ( $\mathrm{n}^{\circ} 15,20,25,30,32,35,38,41,45$, and 48) might be an indicator for evaporation of the recharge water before its infiltration to the aquifer.

The isotopic data for the groundwater collected in the wet season were linearly fit using the regression equation $\delta^{2} \mathrm{H}$ $(\%)=4,01 * \delta^{18} \mathrm{O}(\% \mathrm{o})-8,37\left(R^{2}=0,82\right)$. This regression line can be interpreted as the groundwater evaporation line (GEL). The gel has a $\delta^{2} \mathrm{H} / \delta^{18} \mathrm{O}$ slope $<8$, which reflects evaporation during or after rainfall and/or mixing with an external water source (e.g., return of irrigation water) with high $\delta^{18} \mathrm{O}$ and $\delta^{2} \mathrm{H}$ values. Furthermore, the GEL of the wet season intersected the LMWL at values of $\delta^{18} \mathrm{O}=-5,22 \%$ versus $\mathrm{V}$-SMOW and $\delta^{2} \mathrm{H}=-29,37 \%$ versus $\mathrm{V}$-SMOW. These values are estimated as baseline for $\delta^{2} \mathrm{H}$ and $\delta^{18} \mathrm{O}$ in recharging rainfall (Figures 15(b) and 15(c)). If samples are plotted above the lines, significant groundwater evaporation process can be confirmed.

Additionally, the isotopic data from the dry season were linearly fit using the regression equation $\delta^{2} \mathrm{H}(\% \mathrm{o})=3,09 *$ $\delta^{18} \mathrm{O}(\% \mathrm{o})-11,81$ (with a correlation coefficient $R^{2}=0,83$ ). The GEL has a smaller slope than the LMWL, because evaporation tends to enrich heavy isotopes in water $([19,57])$. The increase in groundwater salinity due to evaporation can thus result in simultaneous increase in heavy isotopes $([19,35])$. The GEL of the dry season intersects the LMWL at values of $\delta^{18} \mathrm{O}=$ $-4,93 \%$ versus $\mathrm{V}-\mathrm{SMOW}$ and $\delta^{2} \mathrm{H}=-27,32 \%$ versus $\mathrm{V}$ SMOW, which are chosen as baselines (Figures 15(d) and $15(\mathrm{e}))$. It is observed that $80 \%$ of the groundwater samples were plotted above the baselines and this demonstrates that evaporation has a significant contribution to groundwater salinity in the study area.

Furthermore, the deuterium excess calculated as d-excess $=\delta^{2} \mathrm{H}-8 \delta^{18} \mathrm{O}$ [54] has been widely used in hydrological studies. The d-excess is used to identify secondary processes that influence the atmospheric vapor content in the evaporation-condensation cycle in nature $([54,58])$. The $\mathrm{d}-$ excess plotted against $\delta^{18} \mathrm{O}$ shows a negative correlation for the whole set of samples (Figure 16). The decrease in d-excess

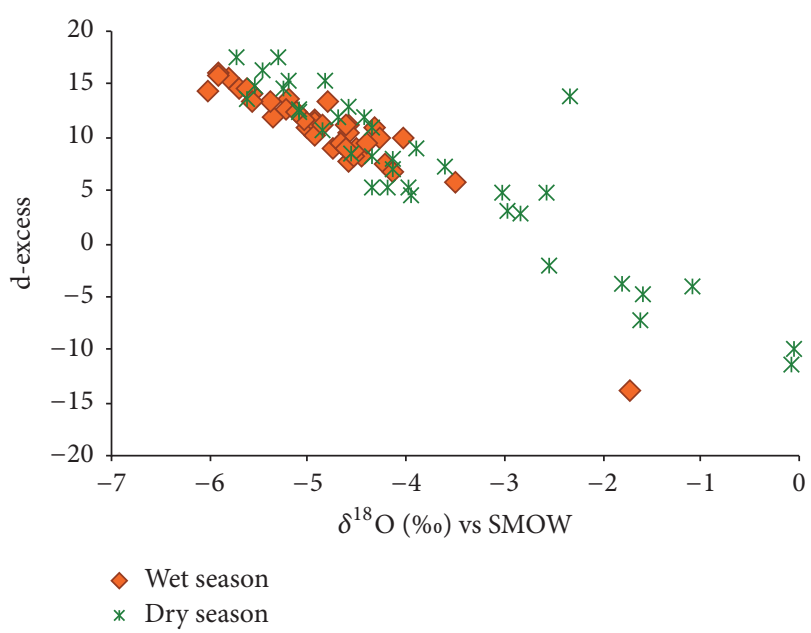

Figure 16: Plot of d-excess versus $\delta^{18} \mathrm{O}$.

is an indication that evaporation has occurred during the recharge process which again confirms the previous results.

4.4. Irrigation Return Flow. Irrigation return flow is defined as the excess of irrigation water that is not evapotranspirated or evacuated by direct surface drainage and which returns to an aquifer or surface water $[59,60]$. Irrigation return flows may induce salt and nitrate pollution of receiving water bodies [61]. Indeed, $\mathrm{NO}_{3}{ }^{-}$is the most common water contaminant, and $\mathrm{NO}_{3}{ }^{-}$pollution is increasing because the number of anthropogenic sources is increasing [26].

$71 \%$ of groundwater samples are contaminated by nitrates where the concentration exceeds the permissible value of 50 $\mathrm{mg} / \mathrm{l}$ set by WHO [62]. The spatial distribution of nitrates (Figure 17) shows that high nitrate contents are observed especially in the upstream of Ras Jbel aquifer. Groundwater contamination by nitrate is due to the intensive use of nitrogen fertilizers $\left(\mathrm{Ca}\left(\mathrm{NO}_{3}\right)_{2}, \mathrm{KNO}_{3}\right.$, and $\left.\mathrm{MgSO}_{4}\right)$. In recent years, the agricultural land area in Ras Jbel plain has increased and copious amounts of nitrogenous fertilizer have been used, which have increased the groundwater $\mathrm{NO}_{3}{ }^{-}$concentrations.

Furthermore, return flow from irrigation water also seems to contribute notably to the recharge process. Most of groundwater samples shows a correlation between $\mathrm{NO}_{3}$ and $\delta^{18} \mathrm{O}$, reflecting the significant role of evaporated and contaminated irrigation water to the groundwater salinization (Figure 18(a)). Huge quantities of irrigation return flow 


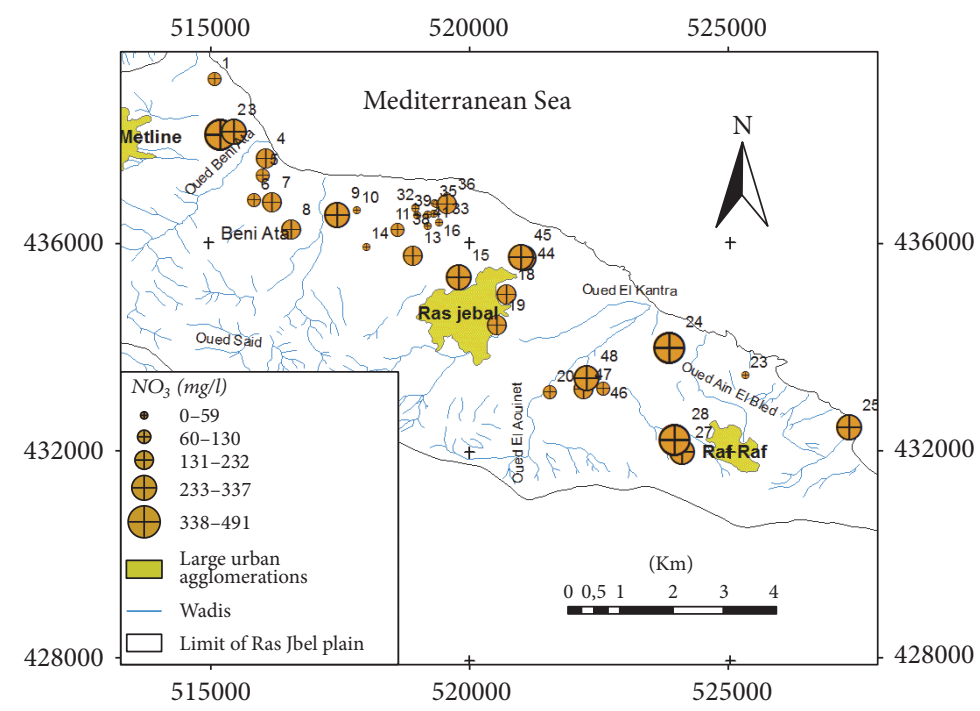

FIGURE 17: Spatial distribution of nitrate concentrations in the shallow aquifer of Ras Jbel during the dry season.

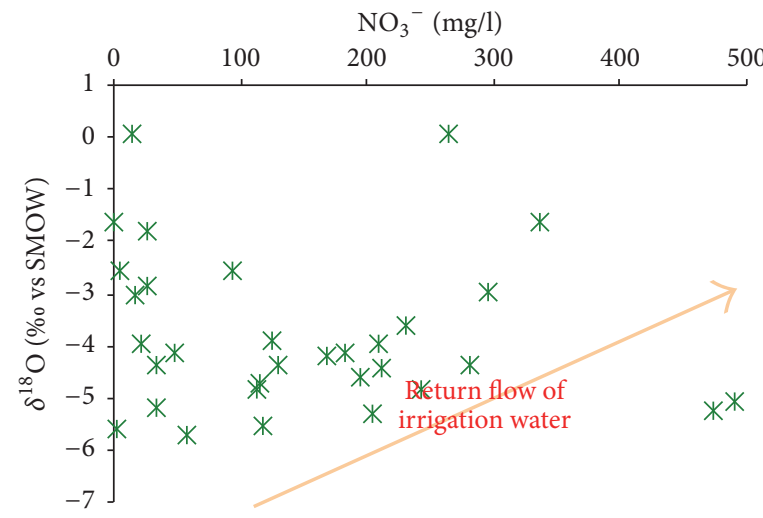

(a)

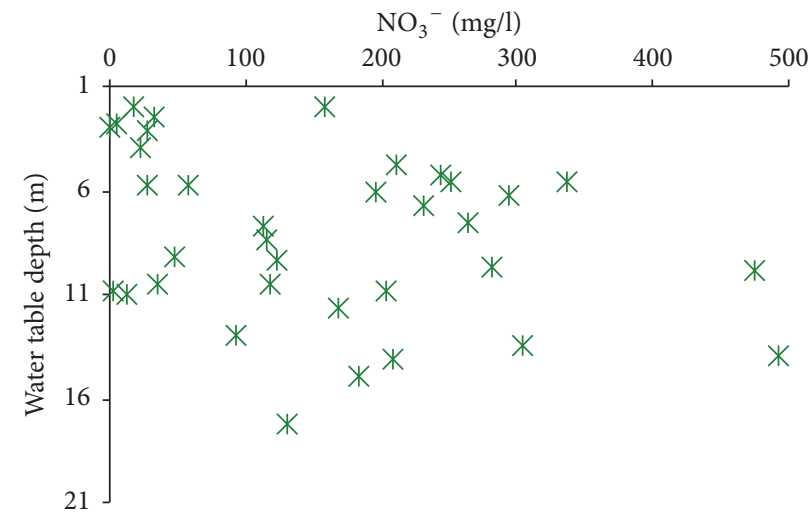

(b)

FIGURE 18: Plots of $\mathrm{NO}_{3}{ }^{-}$versus water table depth and $\delta^{18} \mathrm{O}$ versus $\mathrm{NO}_{3}{ }^{-}$.

elevated groundwater level, hence increasing evaporation and inducing salinization [63]. As highlighted in Figure 18(b), the contamination by return of irrigation water is observed in the shallower horizons (depth $\leq 13 \mathrm{~m}$ ).

\section{Conclusions}

This paper aimed to discuss the origin, processes, and mechanisms of groundwater salinization, as well as the chemical evolution of groundwater in the Ras Jbel coastal aquifer using isotopic tools and hydrochemical tracers.

Most of the groundwater is considered to be of brackish to saline water and contains high ion concentrations. The groundwater in the study area is influenced by both natural and anthropogenic factors. The major geochemical processes controlling hydrochemical evolution are the inverse cationic exchange due to the phenomena of seawater intrusion, dissolution of evaporates minerals (halite, gypsum, and/or anhydrite), irrigation return flow, water-rock interactions, and evapo(transpi)ration. (Figure 19). The mixing rate among freshwater and saline water ranges between 1 and 13\%.

In addition, groundwater in the shallow aquifer of Ras Jbel is also contaminated by agricultural fertilizers containing high amounts of nitrates. Nitrates are transported to the aquifer by natural recharge process and by return flow from irrigation water.

Hydrogen and oxygen-18 stable isotopes signatures of groundwater have identified recent groundwater recharge by infiltration of local precipitations. The enrichment in stable isotope of groundwater confirms that return flow of irrigation waters is an important factor influencing groundwater quality.

The results of this study can be used to improve our understanding of hydrogeochemical processes and enable the protection and sustainable use of water resources. It, therefore, calls for more comprehensive research for better water resources management. 


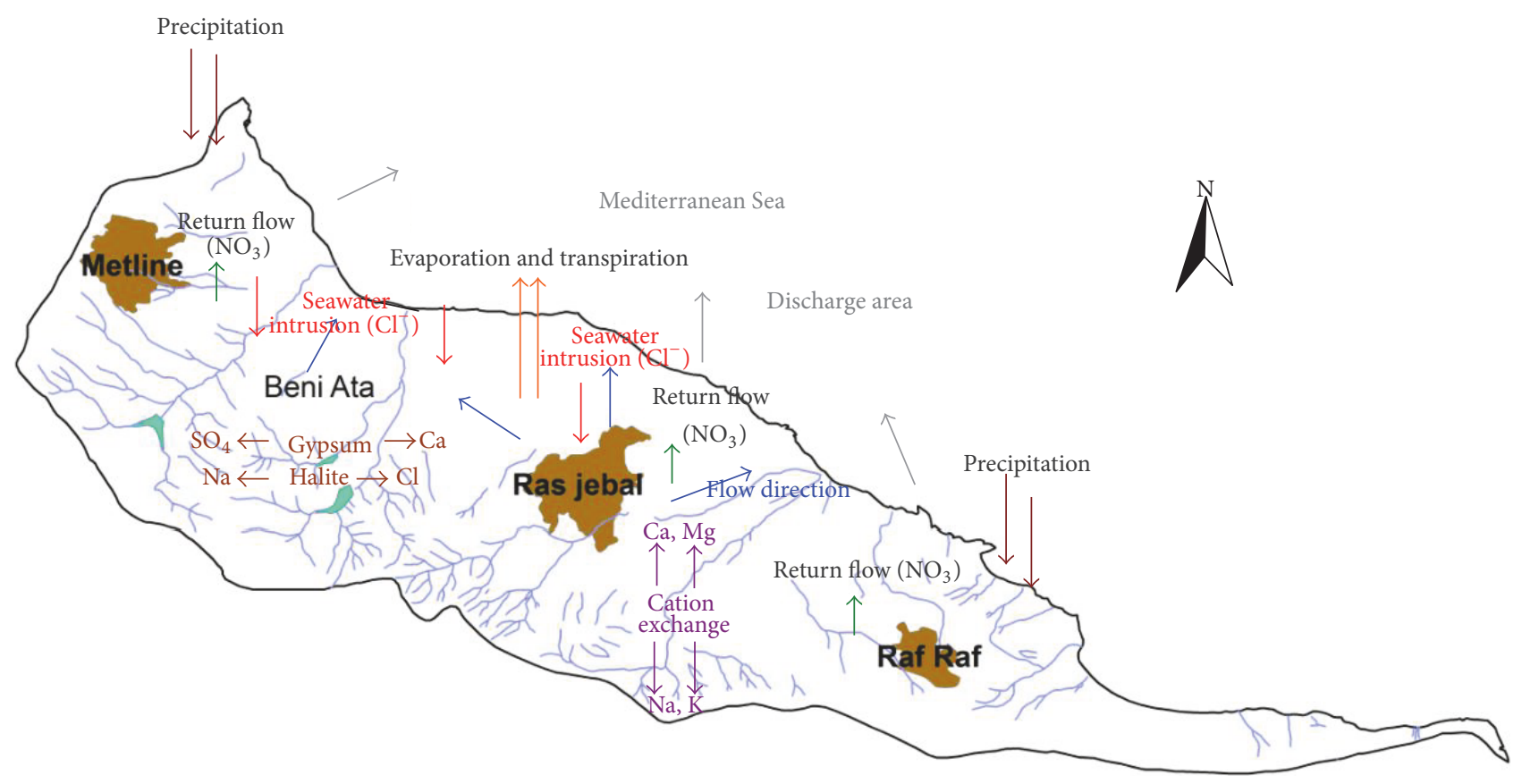

FIGURE 19: Schematic conceptual model summarizing salinization sources of groundwater in the plain of Ras Jbel.

\section{Conflicts of Interest}

The authors declare no conflicts of interest.

\section{Acknowledgments}

The authors would like to gratefully acknowledge all members of the Regional Commission for Agricultural Development of Bizerte for their guidance and support in field campaigns. Special thanks are due to Dr. Maarten Waterloo, Senior hydrologist, Acacia Water (Formerly Professor in Hydrology, Free University Amsterdam), Netherlands.

\section{References}

[1] V. E. A. Post, Groundwater salinization processes in the coastal area of the Netherlands due to transgressions during the Holocene [Ph.D. thesis], University of Amsterdam, Amsterdam, the Netherlands, 2004.

[2] G. de Marsily, "Importance of the maintenance of temporary ponds in arid climates for the recharge of groundwater," Comptes Rendus-Geoscience, vol. 335, no. 13, pp. 933-934, 2003.

[3] D. Han, X. Song, M. J. Currell, G. Cao, Y. Zhang, and Y. Kang, "A survey of groundwater levels and hydrogeochemistry in irrigated fields in the Karamay Agricultural Development Area, northwest China: implications for soil and groundwater salinity resulting from surface water transfer for irrigation," Journal of Hydrology, vol. 405, no. 3-4, pp. 217-234, 2011.

[4] M. U. Igboekwe and A. Ruth, "Groundwater recharge through infiltration process: A Case Study of Umudike, Southeastern Nigeria," Journal of Water Resource and Protection, vol. 3, no. 5, pp. 295-299, 2011.
[5] P. Banerjee and V. S. Singh, "Statistical approach for comprehensive planning of watershed development through artificial recharge," Water Resources Management, vol. 26, no. 10, pp. 2817-2831, 2012.

[6] J. Jing, Q. Hui, C. Yu-Fei, and X. Wen-Juan, "Assessment of groundwater quality based on matter element extension model," Journal of Chemistry, vol. 2013, Article ID 715647, 7 pages, 2013.

[7] L. Kouzana, R. Benassi, A. Ben mammou, and M. Sfar felfoul, "Geophysical and hydrochemical study of the seawater intrusion in Mediterranean semi arid zones. Case of the Korba coastal aquifer (Cap-Bon, Tunisia)," Journal of African Earth Sciences, vol. 58, no. 2, pp. 242-254, 2010.

[8] R. Trabelsi, K. Abid, K. Zouari, and H. Yahyaoui, "Groundwater salinization processes in shallow coastal aquifer of Djeffara plain of Medenine, Southeastern Tunisia," Environmental Earth Sciences, vol. 66, no. 2, pp. 641-653, 2012.

[9] A. Chekirbane, M. Tsujimura, A. Kawachi, H. Isoda, J. Tarhouni, and A. Benalaya, "Hydrogeochemistry and groundwater salinization in an ephemeral coastal flood plain: Cap Bon, Tunisia," Hydrological Sciences Journal, vol. 58, no. 5, pp. 1097-1110, 2013.

[10] H. Bouzourra, R. Bouhlila, L. Elango, F. Slama, and N. Ouslati, "Characterization of mechanisms and processes of groundwater salinization in irrigated coastal area using statistics, GIS, and hydrogeochemical investigations," Environmental Science and Pollution Research, vol. 22, no. 4, pp. 2643-2660, 2015.

[11] A. Kharroubi, S. Farhat, B. Agoubi, and Z. Lakhbir, "Assessment of water qualities and evidence of seawater intrusion in a deep confined aquifer: case of the coastal Djeffara aquifer (Southern Tunisia)," Journal of Water Supply, vol. 63, no. 1, pp. 76-84, 2014.

[12] I. Triki, N. Trabelsi, M. Zairi, and H. Ben Dhia, "Multivariate statistical and geostatistical techniques for assessing groundwater salinization in Sfax, a coastal region of eastern Tunisia," Desalination and Water Treatment, vol. 52, no. 10-12, pp. 19801989, 2014. 
[13] M. F. B. Hamouda, A. J. Kondash, N. Lauer, L. Mejri, J. Tarhouni, and A. Vengosh, "Assessment of groundwater salinity mechanisms in the coastal aquifer of el haouaria, Northern Tunisia," Procedia Earth and Planetary Science, vol. 13, pp. 194-198, 2015.

[14] S. K. Ambast, N. K. Tyagi, and S. K. Raul, "Management of declining groundwater in the Trans Indo-Gangetic Plain (India): some options," Agricultural Water Management, vol. 82, no. 3, pp. 279-296, 2006.

[15] A. El-Naqa and A. Al-Shayeb, "Groundwater protection and management strategy in Jordan," Water Resources Management, vol. 23, no. 12, pp. 2379-2394, 2009.

[16] J. L. McCallum, R. S. Crosbie, G. R. Walker, and W. R. Dawes, "Impacts of climate change on groundwater in Australia: a sensitivity analysis of recharge," Hydrogeology Journal, vol. 18, no. 7, pp. 1625-1638, 2010.

[17] J. D. Ayotte, M. Belaval, S. A. Olson et al., "Factors affecting temporal variability of arsenic in groundwater used for drinking water supply in the United States," Science of the Total Environment, vol. 505, pp. 1370-1379, 2015.

[18] J. Wu and Z. Sun, "Evaluation of shallow groundwater contamination and associated human health risk in an alluvial plain impacted by agricultural and industrial activities, Mid-west China," Exposure and Health, vol. 8, no. 3, pp. 311-329, 2016.

[19] P. Li, J. Wu, and H. Qian, "Hydrochemical appraisal of groundwater quality for drinking and irrigation purposes and the major influencing factors: a case study in and around Hua County, China," Arabian Journal of Geosciences, vol. 9, no. 1, article 15, 2016.

[20] DGRE, Annuaire de Surveillance Piézométrique, Rapp. Int. Ministère de l'Agriculture, Tunis, Tunisia, 2007.

[21] A. Choura, Impact de la surexploitation et de la recharge artificielle de la nappe de Ras Jbel par les systèmes d'information géographiques [M.S. thesis], Faculty of Sciences of Tunis, 1993.

[22] L. Bouchaou, J. L. Michelot, A. Vengosh et al., "Application of multiple isotopic and geochemical tracers for investigation of recharge, salinization, and residence time of water in the SoussMassa aquifer, southwest of Morocco," Journal of Hydrology, vol. 352, no. 3-4, pp. 267-287, 2008.

[23] F. El Yaouti, A. El Mandour, D. Khattach, J. Benavente, and O. Kaufmann, "Salinization processes in the unconfined aquifer of Bou-Areg (NE Morocco): a geostatistical, geochemical, and tomographic study," Applied Geochemistry, vol. 24, no. 1, pp. 1631, 2009.

[24] F. Sdao, S. Parisi, D. Kalisperi et al., "Geochemistry and quality of the groundwater from the karstic and coastal aquifer of Geropotamos River Basin at north-central Crete, Greece," Environmental Earth Sciences, vol. 67, no. 4, pp. 1145-1153, 2012.

[25] G. Mongelli, S. Monni, G. Oggiano, M. Paternoster, and R. Sinisi, "Tracing groundwater salinization processes in coastal aquifers: a hydrogeochemical and isotopic approach in the Na$\mathrm{Cl}$ brackish waters of northwestern Sardinia, Italy, Hydrology and Earth System Sciences, vol. 17, no. 7, pp. 2917-2928, 2013.

[26] Y. Lu, C. Tang, J. Chen, and J. Chen, "Groundwater recharge and hydrogeochemical evolution in leizhou peninsula, China," Journal of Chemistry, vol. 2015, Article ID 427579, 12 pages, 2015.

[27] M. Ennabli, "Hydrogéologie de la plaine de Ras Jbel-Raf Raf," Annales des Mines et de la Géologie, vol. 26, pp. 537-561, 1973.

[28] M. H. Hamza, Evaluation de la vulnérabilité a la pollution des nappes phréatiques de Ras Jbel et de Guenniche par les méthodes paramétriques DRASTIC, SINTACS, et SI appliquées par les systèmes d'informations géographiques [Ph.D. thesis], Faculty of Sciences of Tunis, Tunis, Tunisia, 2007.
[29] P. F. Burollet, "Etude géologique des bassins Mio-Pliocènes du Nord Est de la Tunisie," Annales des Mines et de la Géologie, no. 7, p. 82, 1951.

[30] M. Ennabli, "Etat des travaux réalisés dans la plaine de Metline-Ras Jbel-Raf Raf en vue de l'étude hydrogéologique de la plaine côtière," Rapp. Interne, Bureau de l'Inventaire et des Ressources Hydrauliques, 1969.

[31] DGRE, “Annuaires de surveillance piézométrique," DGRE. Rapports Techniques des Piézomètres et des Forages, Rapp. Int. Ministère de l'Agriculture, Tunis, Tunisia, 1986-2006.

[32] Pimienta, Etude hydrogéologiquede Ras Jebel. Fasc.1 et 2, Service Géologique, (BIRH 3-10 et 3-11), 1949.

[33] I. D. Clark and P. Fritz, Environmental Isotopes in Hydrogeology, Lewis Publishers, New York, NY, USA, 1997.

[34] A. M. Piper, "A graphic procedure in the geochemical interpretation of water-analyses," Eos, Transactions American Geophysical Union, vol. 25, no. 6, pp. 914-928, 1944.

[35] F. Liu, X. Song, L. Yang et al., "Identifying the origin and geochemical evolution of groundwater using hydrochemistry and stable isotopes in the Subei Lake basin, Ordos energy base, Northwestern China," Hydrology and Earth System Sciences, vol. 19, no. 1, pp. 551-565, 2015.

[36] R. J. Gibbs, "Mechanisms controlling world water chemistry," Science, vol. 170, no. 3962, pp. 1088-1090, 1970.

[37] J. W. Lloyd and J. Heathcote, Natural Inorganic Hydrochemistry in Relation to Groundwater, Oxford University Press, New York, NY, USA, 1985.

[38] D. L. Parkhurst and C. Appelo, "PHREEQC2 user's manual and program," Water-Resources Investigations Report, US Geological Survey, Denver, Colo, USA, 2004.

[39] K. Pazand, A. Hezarkhani, Y. Ghanbari, and N. Aghavali, "Groundwater geochemistry in the Meshkinshahr basin of Ardabil province in Iran," Environmental Earth Sciences, vol. 65, no. 3, pp. 871-879, 2012.

[40] D. Sujatha and B. R. Reddy, "Quality characterization of groundwater in the south-eastern part of the Ranga Reddy district, Andhra Pradesh, India," Environmental Geology, vol. 44, no. 5, pp. 579-586, 2003.

[41] A. Kharroubi, F. Tlahigue, B. Agoubi, C. Azri, and S. Bouri, "Hydrochemical and statistical studies of the groundwater salinization in Mediterranean arid zones: case of the Jerba coastal aquifer in southeast Tunisia," Environmental Earth Sciences, vol. 67, no. 7, pp. 2089-2100, 2012.

[42] J. C. Rozemeijer, Dynamics in groundwater and surface water quality: from field-scale processes to catchment-scale monitoring [Ph.D. thesis], Utrecht University, Utrecht, The Netherlands, 2010.

[43] Q. B. Luo, W. D. Kang, Y. L. Xie, and B. F. Zhao, "Groundwater hydro-geochemistry simulation in the Jingbian area of the Luohe of Cretaceous," Ground Water, vol. 30, no. 6, pp. 22-24, 2008.

[44] N. Ettayfi, L. Bouchaou, J. L. Michelot et al., "Geochemical and isotopic (oxygen, hydrogen, carbon, strontium) constraints for the origin, salinity, and residence time of groundwater from a carbonate aquifer in the Western Anti-Atlas Mountains, Morocco," Journal of Hydrology, vol. 438-439, pp. 97-111, 2012.

[45] C. A. J. Appelo and D. Postma, Geochemistry, Groundwater and Pollution, Balkema, Rotterdam, The Netherlands, 2nd edition, 1993.

[46] A. W. Hounslow, Water Quality Data. Analysis and Interpretation, Lewis Publishers, Boca Raton, Fla, USA, 1995. 
[47] M. S. Andersen, V. Nyvang, R. Jakobsen, and D. Postma, "Geochemical processes and solute transport at the seawater/ freshwater interface of a sandy aquifer," Geochimica et Cosmochimica Acta, vol. 69, no. 16, pp. 3979-3994, 2005.

[48] H. Schoeller, "Qualitative evaluation of groundwater resources," in Methods and Techniques of Groundwater Investigations and Development, pp. 53-83, UNESCO, Paris, France, 1965.

[49] B. C. Richter and C. W. Kreitler, "Identification of sources of ground-water salinization using geochemical techniques," p. 273, 1993.

[50] E. Custodio and K. A. Bruggeman, Groundwater Problems in Coastal Areas. Studies and Reports in Hydrology, UNESCO, Paris, France, 1987.

[51] E. Custodio, Groundwater Problems in Coastal Areas, Studies and Reports in Hydrology, UNESCO, Paris, France, 1987.

[52] W. M. Edmunds, A. H. Guendouz, A. Mamou, A. Moulla, P. Shand, and K. Zouari, "Groundwater evolution in the Continental Intercalaire aquifer of southern Algeria and Tunisia: trace element and isotopic indicators," Applied Geochemistry, vol. 18, no. 6, pp. 805-822, 2003.

[53] T. W. Butler II, "Application of multiple geochemical indicators, including the stable isotopes of water, to differentiate water quality evolution in a region influenced by various agricultural practices and domestic wastewater treatment and disposal," Science of the Total Environment, vol. 388, no. 1-3, pp. 149-167, 2007.

[54] W. Dansgaard, "Stable isotopes in precipitation," Tellus, vol. 16, no. 4, pp. 436-468, 1964.

[55] M. Ahmed Maliki, M. Krimissa, J. Michelot, and K. Zouari, "Relation entre nappes superficielles et aquifère profond dans le bassin de Sfax (Tunisie)," Comptes Rendus de l'Académie des Sciences. Series IIA, vol. 331, no. 1, pp. 1-6, 2000.

[56] A. Ben Moussa, S. B. H. Salem, K. Zouari, and F. Jlassi, "Hydrochemical and isotopic investigation of the groundwater composition of an alluvial aquifer, Cap Bon Peninsula, Tunisia," Carbonates and Evaporites, vol. 25, no. 3, pp. 161-176, 2010.

[57] H. Qian, P. Li, J. Wu, and Y. Zhou, "Isotopic characteristics of precipitation, surface and ground waters in the Yinchuan plain, Northwest China," Environmental Earth Sciences, vol. 70, no. 1, pp. 57-70, 2013.

[58] H. Craig, "Isotopic variations in meteoric waters," Science, vol. 133, no. 3465, pp. 1702-1703, 1961.

[59] B. Dewandel, J.-M. Gandolfi, D. de Condappa, and S. Ahmed, "An efficient methodology for estimating irrigation return flow coefficients of irrigated crops at watershed and seasonal scale," Hydrological Processes, vol. 22, no. 11, pp. 1700-1712, 2008.

[60] Z. Kattan, "Estimation of evaporation and irrigation return flow in arid zones using stable isotope ratios and chloride massbalance analysis: case of the Euphrates River, Syria," Journal of Arid Environments, vol. 72, no. 5, pp. 730-747, 2008.

[61] J. Causapé, D. Quílez, and R. Aragüés, “Assessment of irrigation and environmental quality at the hydrological basin level: II. Salt and nitrate loads in irrigation return flows," Agricultural Water Management, vol. 70, no. 3, pp. 211-228, 2004.

[62] WHO, Guidelines for Drinking Water Quality, World Health Organization, Geneva, Switzerland, 3rd edition, 2004.

[63] H. Wu, J. Chen, H. Qian, and X. Zhang, "Chemical characteristics and quality assessment of groundwater of exploited aquifers in Beijiao water source of Yinchuan, China: a case study for drinking, irrigation, and industrial purposes," Journal of Chemistry, vol. 2015, Article ID 726340, 14 pages, 2015.
[64] M. A. Haddad, Evolution de l'État de la Nappe de Ras Jebel de 1949 à 2005 et éValuation des Impacts de la Recharge Artificielle (Période 1992-2005), P.F.E du Cycle d’Ingénieur en Géosciences, Faculté des Sciences de Tunis, 2006.

[65] DGRE, "Annuaires d'exploitation des nappes phréatiques en Tunisie," DGRE, Tunis, Tunisia, 1993-2008. 

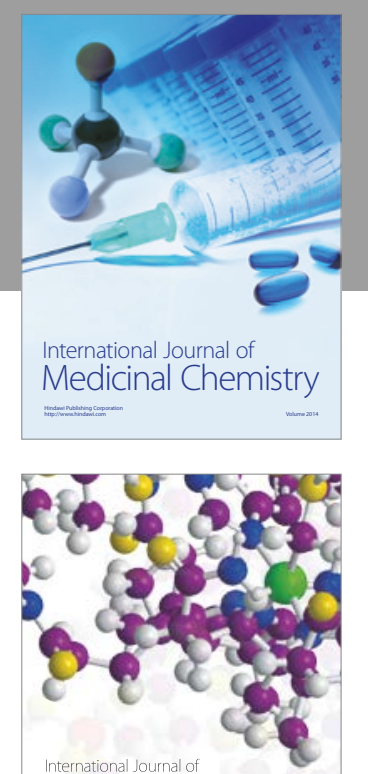

Carbohydrate Chemistry

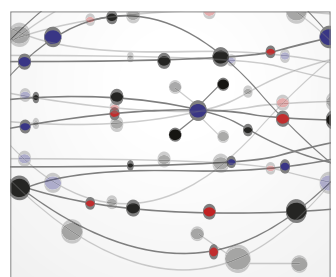

The Scientific World Journal
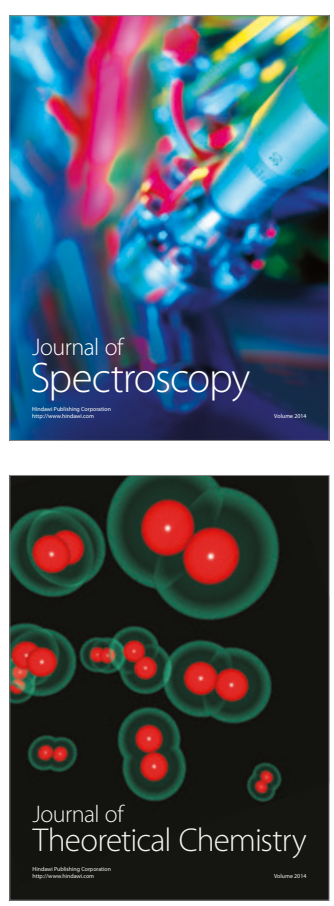
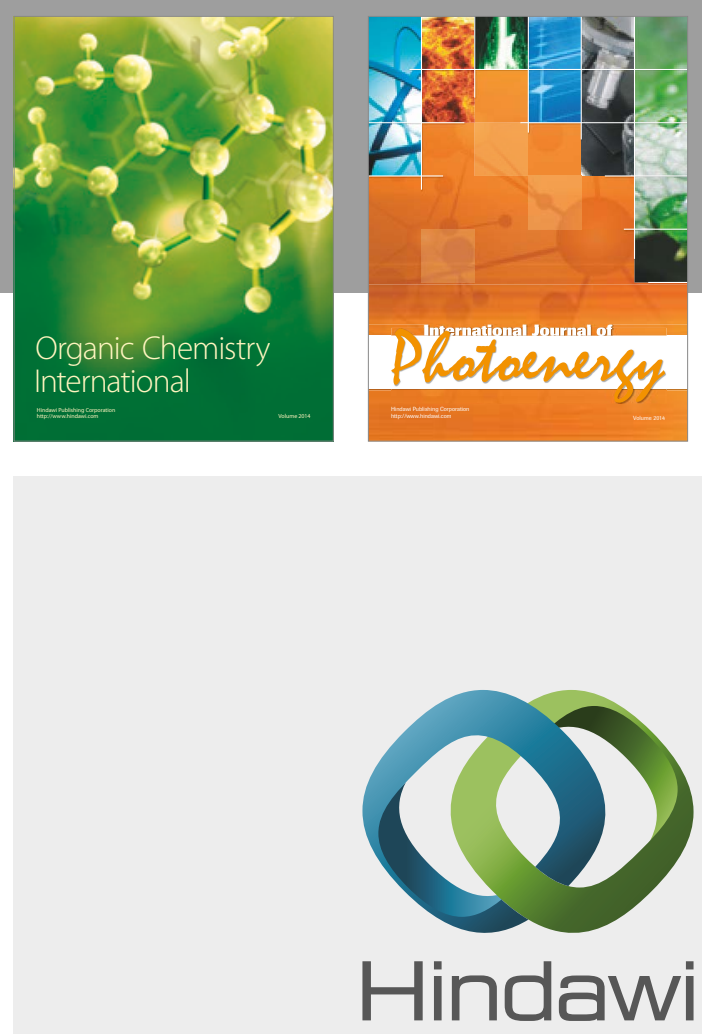

Submit your manuscripts at

https://www.hindawi.com

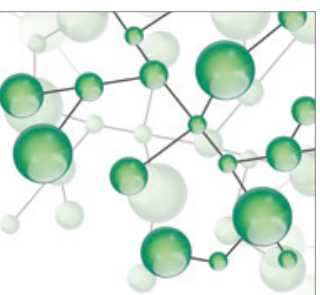

International Journal of

Inorganic Chemistry

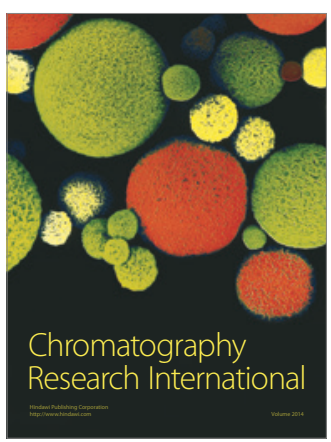

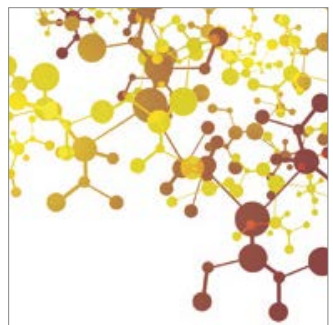

Applied Chemistry
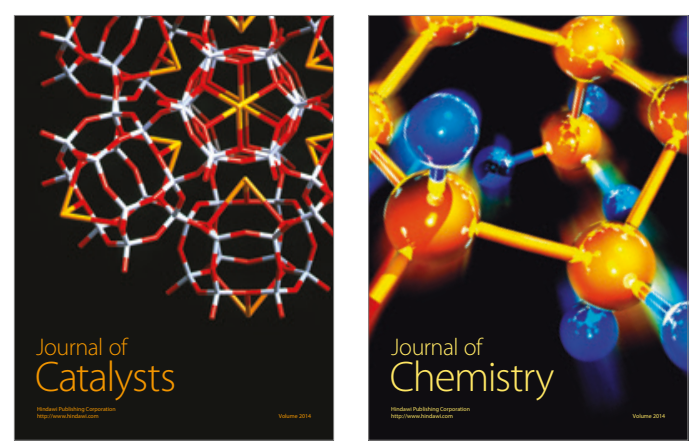
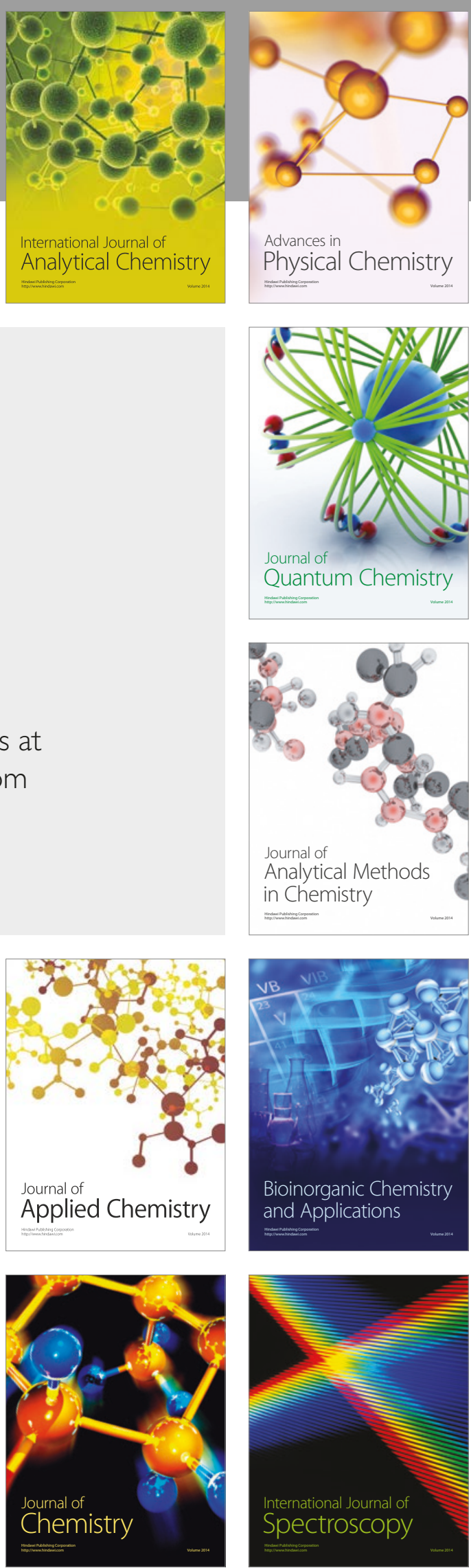